\title{
Carbohydrates in plant immunity and plant protection: roles and potential application as foliar sprays
}

\author{
Sophie Trouvelot ${ }^{1}$, Marie-Claire Héloir ${ }^{1}$, Benoît Poinssot ${ }^{1}$, Adrien Gauthier ${ }^{2}$, Franck Paris ${ }^{1}$, \\ Christelle Guillier ${ }^{1}$, Maud Combier ${ }^{1}$, Lucie Trdá ${ }^{1}$, Xavier Daire ${ }^{3}$ and Marielle Adrian ${ }^{1 *}$ \\ 1 Université de Bourgogne, UMR AgroSup/INRA/uB 1347 Agroécologie, Pôle Interactions Plantes-Microorganismes-ERL CNRS 6300, Dijon, France \\ 2 Department of Biosciences, Plant Biology, University of Helsinki, Helsinki, Finland \\ ${ }^{3}$ INRA, UMR AgroSup/INRA/UB 1347 Agroécologie, Pôle Interactions Plantes-Microorganismes-ERL CNRS 6300, Dijon, France
}

Edited by:

Ebrahim Hadavi, Karaj Branch,

Islamic Azad University, Iran

Reviewed by:

Abdullahil Baque, Sher-e-Bangla

Agricultural University, Bangladesh

Fisun G. Çelikel, Ondokuz Mayis

University, Turkey

\section{*Correspondence}

Marielle Adrian, Université de

Bourgogne, UMR AgroSup/INRA/UB

1347 Agroécologie, Pôle Interactions

Plantes-Microorganismes-ERL

CNRS 6300, 17 rue Sully, BP 86510,

21065 Dijon cedex, France

e-mail: marielle.adrian@

u-bourgogne.fr
Increasing interest is devoted to carbohydrates for their roles in plant immunity. Some of them are elicitors of plant defenses whereas other ones act as signaling molecules in a manner similar to phytohormones. This review first describes the main classes of carbohydrates associated to plant immunity, their role and mode of action. More precisely, the state of the art about perception of "PAMP, MAMP, and DAMP (Pathogen-, Microbe-, Damage-Associated Molecular Patterns) type" oligosaccharides is presented and examples of induced defense events are provided. A particular attention is paid to the structure/activity relationships of these compounds. The role of sugars as signaling molecules, especially in plant microbe interactions, is also presented. Secondly, the potentialities and limits of foliar sprays of carbohydrates to stimulate plant immunity for crop protection against diseases are discussed, with focus on the roles of the leaf cuticle and phyllosphere microflora.

Keywords: carbohydrates, oligosaccharides, sugars, immunity, plant defense, signaling, elicitor, phyllosphere microflora

\section{INTRODUCTION}

Plants possess an immune system that allows defending themselves against a wide range of microorganisms including bacteria, oomycetes and fungi (Gomez-Gomez and Boller, 2000; Nürnberger et al., 2004; Zipfel and Felix, 2005; Boller and Felix, 2009). Activation of defense reactions implies the essential step of the microorganism detection by highly conserved molecular patterns called PAMPs (Pathogen Associated Molecular Patterns) or MAMPs (Microbe Associated Molecular Patterns) (Nürnberger et al., 2004; Chisholm et al., 2006; Jones and Dangl, 2006; Boller and Felix, 2009) which are secreted by microorganisms or released from their cell wall by hydrolytic enzymes during interaction with the plant. Their perception during pathogen infection triggers defense reactions known as PAMP-triggered immunity (PTI) (Jones and Dangl, 2006). So they are considered as general elicitors i.e., compounds able to induce plant defenses (Ebel and Cosio, 1994). These general elicitors can also derive from the plant cell walls during plant microbe interactions after hydrolysis by pathogen cell wall degrading enzymes (Vidal et al., 1998; Boudart et al., 2003) and are therefore called DAMPs (Damage-Associated Molecular Patterns). General elicitors belong to various biochemical classes including carbohydrates, lipids, (glyco)peptides and (glyco)proteins. In this paper, attention is paid to "PAMP, MAMP and DAMP type" carbohydrates, their perception by plants and the induced defense events.

In plants, carbohydrates produced by photosynthesis are well known for their essential role as vital sources of energy and carbon skeletons for organic compounds and storage components. Additionally, a pivotal function as signaling molecules, in a manner similar to hormones, has become apparent (Koch, 1996, 2004; Sheen et al., 1999; Rolland et al., 2006; Smeekens et al., 2010) and is nowadays largely investigated. Hence, as they interact with diurnal changes, abiotic and biotic stresses, and hormone signaling, sugars are considered as actors of a complex communication system necessary for the coordination of metabolism with growth, development, and responses to environmental changes and stresses (Rolland et al., 2002, 2006). Sugars, especially the disaccharides sucrose and trehalose, raffinose family oligosaccharides and fructans also play a role regarding ROS produced by plants in response to abiotic stresses. Known plants antioxidants are enzymatic scavengers (superoxide dismutase, ascorbate peroxidase, glutathione peroxidase) and non-enzymatic metabolites (ascorbate, glutathione, $\alpha$-tocopherol). In addition, there is growing evidence for a role of sugars as antioxidants as they possess ROS scavenging properties. Sugars could therefore be considered as key components of an integrated cellular redox network. As this role was recently reviewed in details by Keunen et al. (2013), it was not developed here.

In plant microbe interactions, sugars are essential to fuel the energy required for defenses and serve as signals for the regulation of defense genes (Ehness et al., 1997; Roitsch et al., 2003; Bolton, 2009). The potential key roles of some sugars regarding plant immunity have recently led to the "sweet Immunity" and "sugarenhanced defense" concepts (Bolouri-Moghaddam and Van Den Ende, 2013).

Regarding their roles in plant immunity, the question is to determine whether carbohydrates could be helpful in controlling plant diseases in field conditions (Delaunois et al., 2014). 
Elicitor-induced resistance against pathogens is a strategy of crop protection under investigation (Walters et al., 2013). Hence, pesticides remain largely used to prevent crops from diseases but the secondary effects of some of them regarding the environmental quality, human health, and selection of resistant strains stimulate research for the development of new strategies in a context of sustainable crop production. Various carbohydrates are presently studied and experimented for their possible role as resistance inducers. Among the biggest challenges of this strategy are their low level of penetration through the cuticle, which limits their perception, and their possible alteration and/or metabolism by microorganisms of the phyllosphere.

\section{CARBOHYDRATES AND PLANT IMMUNITY \\ MAIN CLASSES OF CARBOHYDRATES INVOLVED IN PLANT IMMUNITY}

Mono- and disaccharides such as glucose, sucrose or trehalose are the smallest carbohydrates, generally referred as sugars. Oligo- and polysaccharides are naturally occurring complex carbohydrates formed by chains of sugar residues interconnected by glycosidic linkages and with biological regulatory functions (Albersheim et al., 1983). Different structural patterns have been reported and described for oligo-and polysaccharides, including $\beta$-glucans, chitin- and chitosan oligomers, oligogalacturonides, alginates, fucans, carrageenans, and ulvans (Côté and Hahn, 1994; Klarzynski et al., 2000, 2003) (Table 1).

Beta-glucans are ubiquitous in plant and fungal cell walls. The $\beta-1,4$ glucan cellulose is one of the most abundant glucans in plants. Among $\beta-1,3$ glucans, laminarin, a storage polysaccharide from the brown algae Laminaria digitata, has an average degree of polymerization (DP) of 25-33 glucose units with up to three single $\beta$-glucose branches at position 6 (Read et al., 1996; Lepagnol-Descamps et al., 1998; Klarzynski et al., 2000).

Chitin is the second most ubiquitous natural polysaccharide after cellulose. It is not a pure homopolymer but rather an heteropolymer of $\beta$-1,4-linked $N$-acetylglucosamine with a varying percentage of deacetylated glucosamine (Merzendorfer, 2011). Chitin is a major component of fungal cell walls and is also present in the cuticle of non-vertebrates such crustacean shells, insect exoskeletons, and in eggs of parasitic nematodes, protists, algae (Bueter et al., 2013). Chitosan, the deacetylated derivative of chitin produced by chitin deacetylases, is a less common natural polysaccharide. It is notably found in zygomycete cell walls (Mohammadi et al., 2012).

Pectin is the most complex plant cell wall polysaccharide due to the numerous sugar monomers and types of linkages involved in the branched rhamnogalacturonans I and II domains, and to the variable level of esterification of the homogalacturonan domain. Oligogalacturonides (OGAs) are linear molecules composed of oligomers of $\alpha$-1,4-linked galacturonosyl residues more or less esterified with methyl groups, generated by partial acid hydrolysis or by the action of pectinase or pectate lyase (Nothnagel et al., 1983).

Fucans and carrageenans are sulfated polysaccharides present in brown and red algae whereas ulvans are heteropolysaccharides found in green algae Ulva spp. (Stadnik and De Freitas, 2014). The main constituents of ulvan are sulfated rhamnose residues linked to glucuronic acids, resulting in a repeated disaccharide unit
$\beta$-D-glucuronosyl-(1,4)- $\alpha$-L-rhamnose 3-sulfate, called aldobiouronic acid (Lahaye and Robic, 2007).

Alginates, the main extracellular matrix polysaccharides of brown algae, are constituted by poly-D-mannuronic acid ( $\mathrm{M}$ blocks), poly-D-guluronic acid ( $\mathrm{G}$ blocks), and alternated residues of D-mannuronic acid and D -guluronic acid (GM blocks).

\section{"PAMP, MAMP AND DAMP TYPE" CARBOHYDRATES Perception}

PAMPs, MAMPs, and DAMPs are recognized by PRR receptors (Zipfel, 2008; Macho and Zipfel, 2014). Based on the analysis of the Arabidopsis genome, the array of putative PRRs encoded in plants is much higher than in mammals. PRRs for chitin and OGAs have been identified but cognate receptors of other OS, including $\beta$-glucans, chitosan, fucan, etc., are yet unknown.

Plant PRRs are receptor-like kinases (RLKs) or receptor-like proteins (RLPs), which are localized at the plasma membrane and possess extracellular domain for ligand recognition. The major PRR types carry leucine rich repeats (LRR) or lysine motifs (LysM), while others can carry C-type lectin or EGF-like ectodomain (Shiu and Bleecker, 2003). LysM-RLKs and RLPs recognize $\beta$-1,4-linked $N$-acetylglucosamine units containing glycans and aminosugars present on microbial surface, such as fungal chitin and bacterial peptidoglycan, or lipochitooligosaccharides secreted by beneficial microorganisms (Gust et al., 2012).

In Arabidopsis thaliana, the chitin elicitor receptor kinase 1 (CERK1) is the key chitin binding and signaling component (Miya et al., 2007; Wan et al., 2008; Petutschnig et al., 2010). AtCERK1, a LysM-RLK with three LysM domains in the ectodomain, binds chitin directly without any requirement for interacting proteins and initiates signaling via its cytoplasmic Ser/Thr kinase domain (Miya et al., 2007; Wan et al., 2008; lizasa et al., 2010; Petutschnig et al., 2010). In the monocot rice, fungal chitin is recognized by the LysM-RLP Chitin elicitorbinding protein (CEBiP) (Kaku et al., 2006; Hayafune et al., 2014; Kouzai et al., 2014). OsCEBiP is a specific chitin receptor (Kouzai et al., 2014) which cooperates with the chitin elicitor receptor kinase 1 (OsCERK1), the closest homolog of AtCERK1 in rice (Miya et al., 2007; Shimizu et al., 2010; Hayafune et al., 2014). They form a transient hetero-dimer: OsCEBiP for chitin binding and OsCERK1 for initiation of the signal transduction (Shimizu et al., 2010; Hayafune et al., 2014). In wheat, another monocot crop, homologs of CERK1 and CEBiP are both required for chitin-induced defenses (Lee et al., 2014), suggesting conserved CEBiP/CERK1 perception in monocots.

Some PRRs for DAMPs perception have also been identified. The OG receptor identified is the wall-associated kinase 1 (WAK1), a trans-membrane receptor protein kinase belonging to a family of 5 members (WAK1-5) in the Arabidopsis genome (Kohorn and Kohorn, 2012). In this gene family, only the transcripts of WAK1 are significantly up-regulated at 1 and $3 \mathrm{~h}$ after OGA treatment (Denoux et al., 2008). By using a chimeric approach, Brutus et al. (2010) elegantly showed that WAK1 can bind OGAs, thus leading to the activation of its intra-membrane kinase domain to finally trigger plant immune 
responses. Moreover, the binding of OGA to the ectodomain of WAK1 seems to need a specific confirmation of "egg-boxes" complexes formed by calcium bridges (Decreux and Messiaen, 2005; Cabrera et al., 2008).

\section{Induced defenses and resistance}

From what we know, PRRs are often associated with other RLKs or RLPs to form molecular complexes (Böhm et al., 2014). Such formations can improve the ligand recognition,

Table 1 | Structures of the main di- and oligosaccharides reported as elicitors of plant defenses and/or resistance inducers against pathogens.

Carbohydrate Structure or repetitive units
References reporting induction of defenses and/or plant resistance

Rolland et al., 2002; Morkunas et al., 2005; Gómez-Ariza et al., 2007; Wind et al., 2010; Bolouri-Moghaddam and Van Den Ende, 2012, 2013

Reignault et al., 2001; Muchembled et al., 2006; Renard-Merlier et al., 2007; Fernandez et al., 2010; Singh et al., 2011

Trehalose
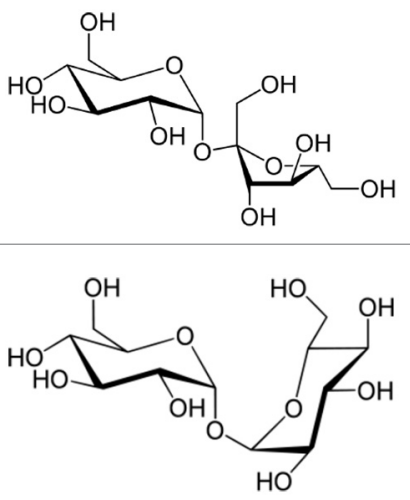

refnander

$\beta-1,3$ glucans: example of laminarin

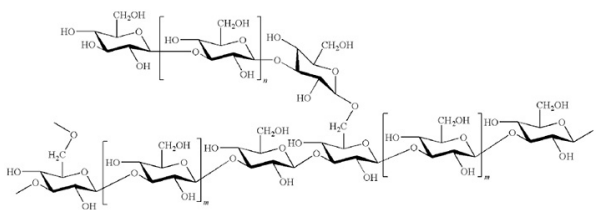

Kobayashi et al., 1993; Inui et al., 1997; Cardinale et al., 2000; Klarzynski et al., 2000; Aziz et al., 2003; Renard-Merlier et al., 2007; Fu et al., 2011; Gauthier et al., 2014
Sulfated $\beta-1,3$ glucans Example of the sulfated laminarin PS3 (Phycarin Sulfated 3)
Ménard et al., 2004; Ghannam et al., 2005; Ménard et al., 2005; Trouvelot et al., 2008; Steimetz et al., 2012; Gauthier et al., 2014

Lizzi et al., 1998; Klarzynski et al., 2003
Fucans

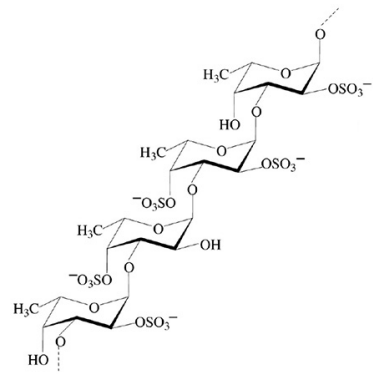

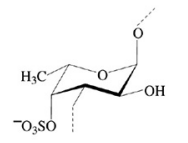

\section{.

(n)

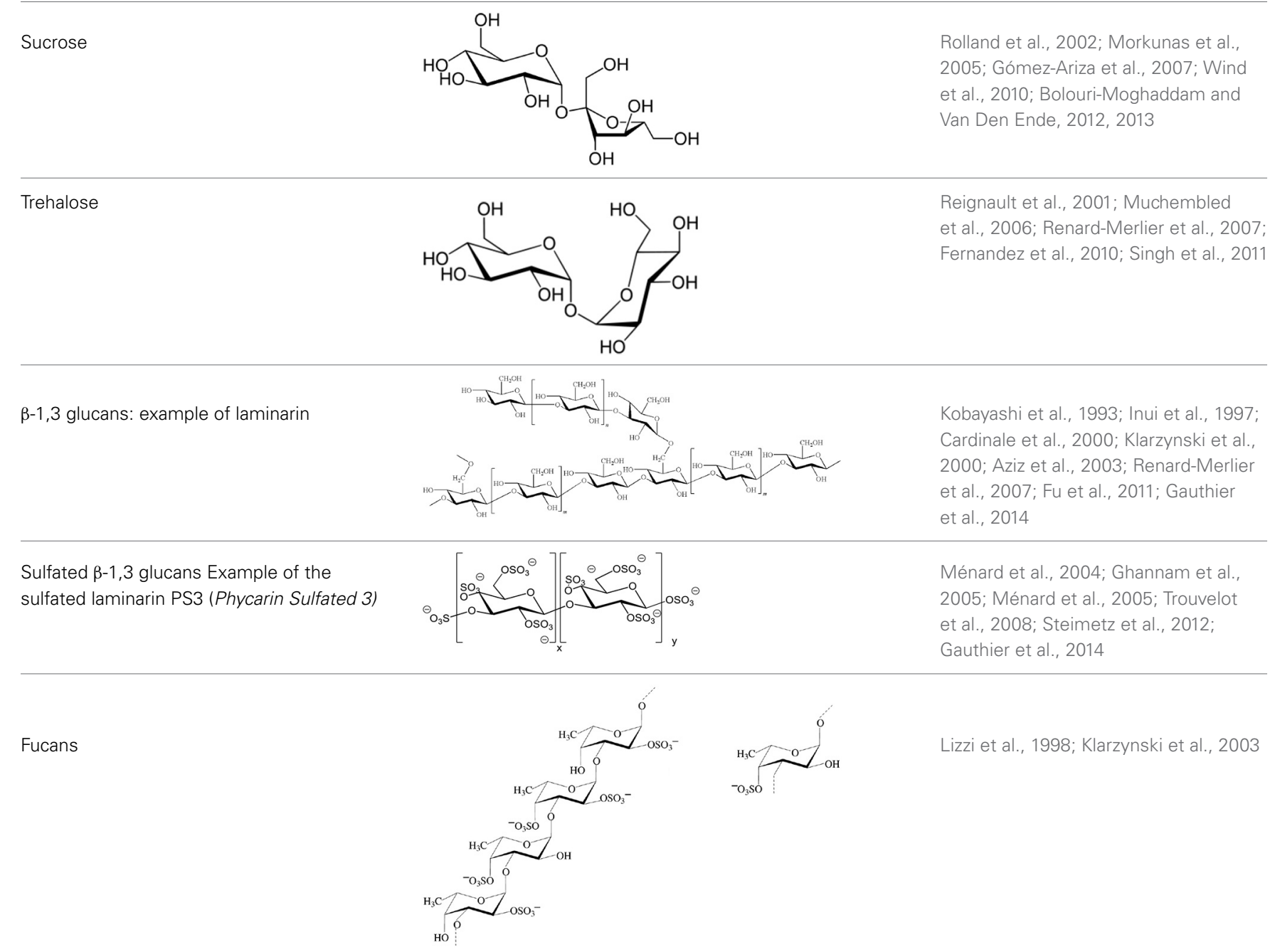

Patier et al., 1995; Bouarab et al., 1999; Mercier et al., 2001; Sangha et al., 2010; Vera et al., 2012

Cluzet et al., 2004; Abreu et al., 2008; Araújo et al., 2008; Borsato et al., 2010; Jaulneau et al., 2010, 2011; Freitas and Stadnik, 2012; Araújo and Stadnik, 2013; Delgado et al., 2013; Stadnik and De Freitas, 2014 
Table 1 | Continued

\section{Carbohydrate}

Structure or repetitive units
References reporting induction of defenses and/or plant resistance

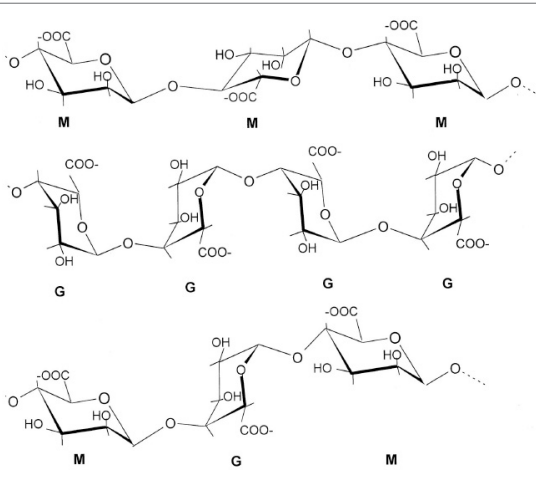

G

Potin et al., 1999; Akimoto et al., 2000; Chandía et al., 2004; An et al., 2009
D-glucuronic acid) (M

blocks: poly

D-mannuronic acid) (GM

blocks: alternate

D-glucuronic and

D-mannuronic acid)
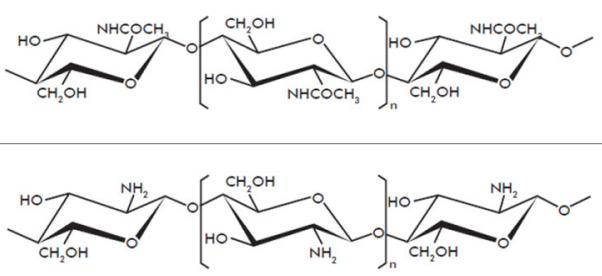

Pearce and Ride, 1982; Kuchitsu et al., 1993; Kaku et al., 2006; Eckardt, 2008; Hamel and Beaudoin, 2010; Sharp, 2013

Köhle et al., 1985; Doares et al., 1995; Lafontaine and Benhamou, 1996; Vasyukova et al., 2001; Cabrera et al., 2006; Amborabe et al., 2008; Iriti and Faoro, 2009; Vasil'ev et al., 2009; Cabrera et al., 2010; El Hadrami et al., 2010; Hamel and Beaudoin, 2010; Li et al., 2014

Hahn et al., 1981; Davis et al., 1986; Davis and Hahlbrock, 1987; Cabrera et al., 2008, 2010; Galletti et al., 2008; Rasul et al., 2012; Ferrari et al., 2013 signal transduction or perform a regulatory role (Monaghan and Zipfel, 2012). Notably RLP receptors interact with RLKs for signal transduction. The recognition of MAMPs/DAMPs leads to the activation of the PRR kinase domain, which initiates phosphorylation and the subsequent complex cascade of signaling events that leads to defense gene activation. Defense gene expression allows the synthesis of pathogenesis-related (PR) proteins (such as the hydrolytic enzymes $\beta$-1,3-glucanases and chitinases, cationic defensin, peroxidases, proteinase inhibitors or lipidtransfer proteins), the accumulation of phytoalexins, and cell wall strengthening.

The first identified elicitor-active oligosaccharides (OS) were $\beta$-glucans produced from Phytophthora megasperma pv. sojae (Ayers et al., 1976). Thereafter, eliciting activity of OS has been largely studied (Table 1). As examples, $\beta$-1,3-glucans elicit defense responses in many species (Sharp et al., 1984; Côté and Hahn, 1994; Côté et al., 1998; Ebel, 1998; Shibuya and Minami, 2001). In particular, laminarin induces defense responses in rice (Inui et al., 1997), tobacco cell suspensions (Klarzynski et al., 2000), alfalfa (Cardinale et al., 2000) and grapevine (Aziz et al., 2003). OGAs also induce various defense responses (Ferrari et al., 2013), such as the synthesis of phytoalexins in soybean and bean (Nothnagel et al., 1983; Dixon et al., 1989), the expression of protease inhibitors in tomato leaves (Farmer et al., 1991), defense genes in Arabidopsis (Denoux et al., 2008), lignification in cucumber hypocotyls (Robertsen, 1986) or the production of active oxygen forms in many plant species (Legendre et al., 1993; Rouet-Mayer et al., 1997; Binet et al., 1998; Stennis et al., 1998; Galletti et al., 2008). Chitin derivatives induce lignification in wheat (Barber et al., 1989), ion fluxes and phosphorylation events in tomato cell suspensions (Felix et al., 1993), chitinase activity in melon (Roby et al., 1987) and the expression of glucanase in barley cells (Kaku et al., 1997). In rice, chitin triggers the MAPK cascade (Yamaguchi et al., 2013), and biosynthesis of phytoalexins and lignin (Kawano and Shimamoto, 2013).

In tomato and Commelina communis, Lee et al. (1999) showed a $\mathrm{H}_{2} \mathrm{O}_{2}$-dependent induction of stomatal closure by chitosan and OGA, as in response to ABA. It was later confirmed in grapevine using $\beta$-glucans and OGA (Allègre et al., 2009) and in tobacco using $\beta$-glucans (Fu et al., 2011). These results unambiguously show that $\mathrm{OS}$ can be also perceived by guard cells (Figure 1), thus leading to signaling, defense activation, and also stomatal movements (generally a stomatal closure). Experiments performed with grapevine leaves also 


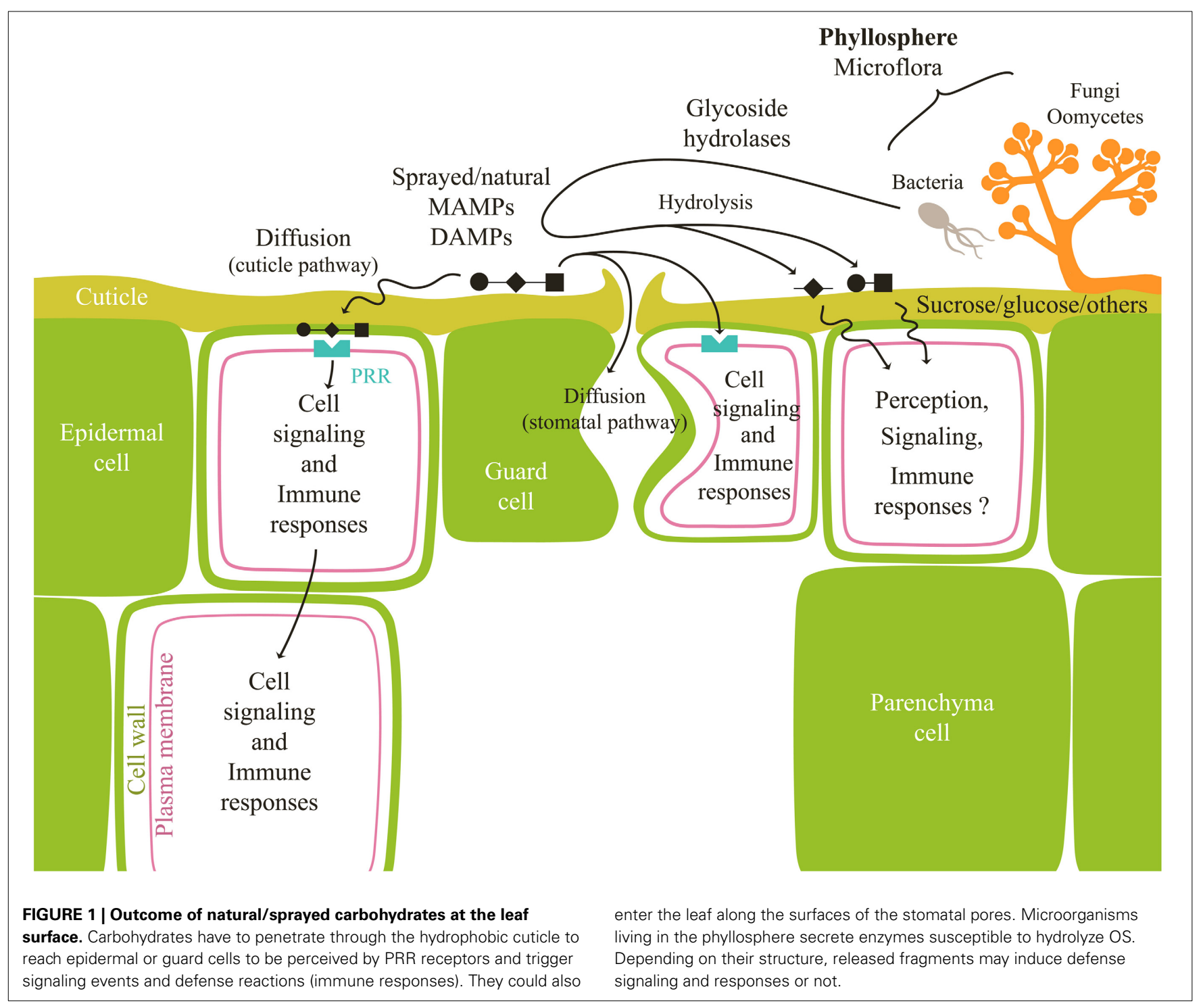

showed a higher responsiveness of guard cells to OS, compared to epidermal cells (Trouvelot et al., 2008; Allègre et al., 2009).

Numerous papers have therefore described the capacity of oligosaccharides to induce plant defenses. However, few of them have reported induced resistance of plants against pathogens. OGAs induce resistance of Arabidopsis against Botrytis cinerea (Aziz et al., 2004; Ferrari et al., 2007). Laminarin confers protection of grapevine against Plasmopara viticola and Botrytis cinerea and of tobacco against tobacco virus mosaic (TVM) (Klarzynski et al., 2000; Aziz et al., 2003). Treatment with chitin reduces the susceptibility of rice to Magnaporthe oryzae (Tanabe et al., 2006). Curiously, the effect of chitin treatment on resistance remains rather mild whereas chitosan induces a strong resistance of different plant species to fungal pathogens (Sharp, 2013). However, besides its elicitor activity (Benhamou et al., 1994), chitosan also possesses antifungal properties (El Ghaouth et al., 1994; Trotel-Aziz et al., 2006).

\section{Structure/activity relationships of carbohydrates}

The biological activity of oligosaccharides is highly dependent on their degree of polymerization (DP) and pattern. Fu et al. (2011) have reported that $\beta$-1,3-glucans with low DP (2-10) induce more rapid responses than laminarin with high DP (25-40) in tobacco cells. Interestingly, they observed the opposite for induced resistance: high DP $\beta$-1,3-glucans being more active than low DP ones against TVM. The highest activity of chitin was generally reported for heptamers and octamers and little or no activity for shorter oligomers (Vander et al., 1998; Hamel and Beaudoin, 2010). For chitosan, oligomers with a DP ranged between 7 and 10 are usually the most active (Hadwiger, 2013). Dissimilar size-depending biological response were also reported for OGAs (Reymond et al., 1995). DP between 10 and 16 are indeed often referred to as optimal size to induce defenses (Navazio et al., 2002; Galletti et al., 2008; Vorhölter et al., 2012). For shorter OGAs with 2-6 DP, the activity is highly dependent on pathosystems. Whereas they induce defense reactions in tomato or potato (Weber et al., 
1996; Simpson et al., 1998), they suppress the elicitor-induced responses in wheat leaves and hypersensitive resistance reaction in genetically resistant plants (Moerschbacher et al., 1990).

Some studies mentioned that plants may have developed the ability to react to structurally different $\beta$-glucans. In particular, soybean and rice recognize only branched $\beta$-glucans (Cheong and Hahn, 1991; Yamaguchi et al., 2000) whereas tobacco reacts to linear $\beta$-1,3-glucans. As example, the $\beta$-1,6- $\beta$-1,3-heptaglucoside elicits phytoalexin accumulation in soybean (Sharp et al., 1984) but is inactive in tobacco (Klarzynski et al., 2000).

Acetylation and methylation also impact OS activity. The chitin acetylation status is crucial for CERK1 binding as AtCERK1 can weakly bind the partially deacetylated chitosan whereas it possesses no affinity for fully deacetylated chitooligomers (Petutschnig et al., 2010). Chitosan heptaose and octaose do not elicit ROS burst and cell death in rice, suggesting that also rice requires acetylated ligands for immune activation (Kaku et al., 2006; Kishimoto et al., 2010). For OGAs, acetylation is also important since both acetylated and unacetylated ones induce defense events in wheat whereas only acetylated ones lead to an increase in papilla-associated fluorescence and to a reduction of formed fungal haustoria of Blumeria graminis f. sp. tritici (Randoux et al., 2010). The degree of methyl esterification of OGAs, modulated by pectin methylesterases (PME), is crucial for their activity (Pelloux et al., 2007). As example, a reduction of B. cinerea symptoms was observed in Arabidopsis plants overexpressing the specific inhibitor of PME (PMEIs) (Lionetti et al., 2007). Conversely, the overexpression of PME in strawberry leads to a reduced degree of methyl esterification of OGA, an increase of defense genes expression and an improved resistance against B. cinerea (Osorio et al., 2008).

Biomolecules substituted with sulfate groups are involved in major physiological functions in plants and animals. The presence of sulfate groups and the degree of sulfation (DS) can modulate the biological activities of oligosaccharides. Laminarin was therefore sulfated to improve its activity, providing PS3 with a DS of 2.4 (Ménard et al., 2004). The addition of a sulfate moiety to glucose residues in the chain is likely to modify the three-dimension structure of the molecule and consequently change its affinity to the assumed receptor (Ménard et al., 2005). Moreover, it confers PS3 resistance to degradation by endo- $\beta-1,3$ glucanases and exo-glucanases. PS3 induces increased resistance responses of tobacco infected with TMV (Ménard et al., 2004) and inhibits both virus infection and multiplication whereas laminarin inhibits only virus infection (Ménard et al., 2005), suggesting two distinct perception systems for laminarin and PS3. Moreover, PS3-enhanced resistance of grapevine herbaceous plantlets against Plasmopara viticola is more efficient than with laminarin (Trouvelot et al., 2008). Interestingly, PS3 acts by priming in this interaction whereas laminarin directly elicits defense events (Trouvelot et al., 2008; Gauthier et al., 2014). A structureactivity study was also conducted for laminarin sulfates having different degrees of sulfation (ranging between 0.4 and 2.4), based on PR-protein activation in tobacco (Ménard et al., 2004). A DS higher than 0.4 is required to trigger $\mathrm{PR}$ proteins and the activity increases with increasing DS. Moreover, the maximal eliciting activity is obtained for DS of at least 1.5 and seems to be independent of the chain length (ranging from a DP of 15 to 25 in this study).

\section{SUGARS AS SIGNALING MOLECULES}

Sugars are also involved in plant immunity as signaling molecules (Sheen et al., 1999; Rolland et al., 2006); this has led to the "sweetimmunity" and "sugar-enhanced defense" concepts (BolouriMoghaddam and Van Den Ende, 2013). It concerns "small sugars" i.e., mono-, di- and small oligosaccharides (saccharide-like) such as sucrose, trehalose, raffinose or galactinol able to activate plant defense responses and increase plant resistance to pathogens. As examples, sucrose induces isoflavonoids synthesis as a defense response against Fusarium oxysporum in lupine (Morkunas et al., 2005). Galactinol stimulates the accumulation of defense-related gene transcripts in tobacco plants, enhances resistance against Botrytis cinerea and Erwinia carotovora and is a signaling component of the induced systemic resistance caused by Pseudomonas chlororaphis (Kim et al., 2008). Trehalose induces PAL and peroxidase activities associated with partial resistance of wheat against powdery mildew (Reignault et al., 2001). In Arabidopsis cell suspensions, sucrose or glucose induces the expression of several PRgenes and accumulation of the corresponding proteins PR-2 and PR-5 through a SA-dependent pathway (Thibaud et al., 2004). Conversely, sucrose, glucose, and fructose induce the PR-protein transcripts $P R-Q$ and $P A R-1$ in tobacco in a SA-independent pathway (Herbers et al., 1996b). As reviewed by Bolouri-Moghaddam and Van Den Ende (2012), other sugars such as psicose or D-allose can stimulate plant immunity and upregulate defense genes expression. It is tempting to think that some sugars could be considered as elicitors. However, plants may respond to changes of extracellular levels of sugars rather than sugars themselves.

How plants perceive sugars is highly complex and needs to be further investigated. The perception of hexoses is achieved by hexokinases (Granot et al., 2013; Tiessen and Padilla-Chacon, 2013) such as the intracellular glucose sensor HXK 1 of Arabidopsis (Jang et al., 1997; Sheen et al., 1999; Smeekens, 2000; Rolland et al., 2006). However, hexokinase independent pathways were also reported (Lalonde et al., 1999; Sheen et al., 1999). Sucrose and other disaccharides seem to be perceived at the level of the plasma membrane (Goddijn and Smeekens, 1998; Rolland et al., 2002, 2006; Schluepmann et al., 2003). However, sucrose can also be hydrolyzed by apoplastic invertases, providing hexoses that will be perceived by membrane or cytosolic sensors (Sheen et al., 1999). Research on sugar transporters is also in progress and will help to decipher the mechanisms associated to sugar perception.

The relationship between plant carbohydrate status and defense/resistance against pathogens has been known from a long time as the "high sugar resistance" (Horsfall and Dimond, 1957). Several papers have since reported changes in apoplastic/cell sugar content, source to sink transition, increase in cell-wall invertase activity and also changes in the sucrose/hexose ratio in plants challenged by pathogens (Bolouri-Moghaddam and Van Den Ende, 2012). Such changes are perceived by plants and allow induction of defenses (Herbers et al., 1996a; Tang et al., 1996; Ehness et al., 1997; Schaarschmidt et al., 2007; Kocal et al., 2008). Invertases, enzymes that catalyze the conversion of sucrose to glucose and fructose, are essential for the modulation of apoplastic 
sugar content (Roitsch et al., 2003; Roitsch and Gonzalez, 2004). Despite their role as simple soluble sugar suppliers (BolouriMoghaddam et al., 2010; Xiang et al., 2011), they play a key role in the regulation of source/sink relations of plants and response to pathogens (Ehness et al., 1997). This is particularly true for apoplastic invertases considered as PR-proteins (Roitsch et al., 2003). Overexpression of a yeast invertase in the apoplast of tobacco hence induces production of PR proteins and increases resistance against virus infection (Herbers et al., 2000). Transcript accumulation and/or increased activity of extracellular invertase were reported in response to glucose, sucrose, non-metabolizable sucrose analogs (Roitsch et al., 2003) and polygalacturonic acid (Godt and Roitsch, 1997). Metabolizable sugars and defense related stimuli (including chitosan) were shown to coordinately regulate source/sink relations and defense responses (Ehness et al., 1997). Such a regulation could contribute to provide energy for defenses and improve the defense response against pathogens (Roitsch et al., 2003). Interestingly, some pathogens seem to be able to bypass this signaling system. Hence, Wahl et al. (2010) have characterized the membrane-localized sucrose transporter Srt1 from the corn fungal biotrophic pathogen Ustilago maydis. Srtl is sucrose specific and acts as a virulence factor as sucrose is directly taken up in the apoplast and not hydrolyzed with the subsequent release of monosaccharides able to induce defenses.

\section{APPLICATION OF OLIGOSACCHARIDES FOR PLANT PROTECTION}

\section{A STILL LIMITED USE}

As stated above, many OS are able to induce plant defenses and, in some cases, plant resistance against pathogens in lab conditions. This has opened the way to applications in crop protection. In this context, OS are attractive candidates as resistance inducers since they are mostly non-toxic, safe to the environment and can be extracted from renewable sources. Numerous field trials with OS have been performed but few of them lead to positive and reproducible results, probably explaining why published results still remain scarce. The following part of this review presents a nonexhaustive list of experimental data representative of the present situation of OS in crop protection.

The glucan laminarin was shown to reduce severity of downy mildew and gray mold in grapevine in lab tests (Aziz et al., 2003). Unfortunately, vineyard trials yielded inconsistent results that precluded further applications for this crop. The situation is seemingly more successful with other interactions. Indeed, in field conditions, several sprays of laminarin on strawberry allowed the control of powdery mildew up to $70-80$ and to $50 \%$ for leaf spot and gray mold.

Chitosan has been studied as plant protectant for more than 30 years and a wealth of publications is available. It is the OS that has given rise to the greatest number of applications (Hadwiger, 2013) in a wide array of plant-pathogen interactions and the induced protection was found to range from significant to null. For example, Iriti et al. (2011) assessed the efficacy of a commercial preparation of $85 \%$ deacetylated chitosan with a high DP (MW of $20-30 \mathrm{KDa}$ ) against grapevine powdery mildew. The solution was sprayed weekly at $40 \mathrm{mg} / \mathrm{l}$ during the susceptibility period of the fruits. The treatment eventually reduced the disease by more than $90 \%$ and increased the polyphenol content of berries, which suggests that this chitosan had affected the secondary metabolism of grapevine. With another commercial formulation, Sharathchandra et al. (2004) recorded up to $65 \%$ of protection against pearl millet downy mildew. According to our own experience, no efficacy of high DP chitosan preparations was observed against grapevine downy mildew in vineyard experiments (Daire, unpublished) whereas $100 \%$ protection was obtained in greenhouse conditions. Most preparations possess a strong antimicrobial activity due to the polycationic nature of the deacetylated glucosamine. Chitosan therefore has a dual role and it is often difficult to establish whether the observed protectant effect relies on the eliciting or on the antimicrobial property or both. In addition one can take advantage of biofilm forming properties of chitosan for post-harvest protection of fruits (Hadwiger, 2013).

Curiously, no published data of crop protection are available for OGAs alone while their eliciting properties have been extensively studied. Chitosan oligomers (both in the decamer range) were combined to OGA in order to stabilize the egg box conformation of the latter and the complex was shown to be a potent elicitor of defense reactions in Arabidopsis (Cabrera et al., 2010). This mixture also elicited defenses in tomato and, in greenhouse conditions, several spray applications achieved $80 \%$ protection against cucumber powdery mildew under high disease pressure. The treatment proved also effective against grapevine powdery mildew in a vineyard experiment in Spain. In this experiment, six sprays throughout the growing season, delivering only $35 \mathrm{~g} / \mathrm{ha}$ of OS each, allowed to reduce disease severity from $54 \%$ in control to $13 \%$ in the treated plots (Van Aubel, 2013). Such results are in agreement with similar trials carried out previously in France (Daire, unpublished).

In spray application, oligosaccharide-induced resistance is often found to be dose dependent. For example, during greenhouse protection tests with sulfated laminarin against grape downy mildew, maximum disease reduction rate reached $85 \%$ with 5 g. $1^{-1}$ of oligosaccharide while it was only $57 \%$ when the dose was lowered to $1.25 \mathrm{~g} . \mathrm{l}^{-1}$ (Trouvelot et al., 2008). This dosedependent effect was also observed in field trials with this OS against powdery mildew (Daire, unpublished data).

As the effectiveness of OS treatments as crop protection against diseases generally still suffers inconsistency (Delaunois et al., 2014), the role of factors susceptible to impact the level of OSinduced resistance of plants is presently investigated to develop this strategy (Walters et al., 2013). Among them are the cuticular barrier and the phyllosphere microflora.

\section{THE CUTICULAR BARRIER}

Once sprayed, elicitors have to go through the cuticular barrier to reach the cell wall and plasma membrane to be perceived. The cuticle, present at the surface of plant aerial organs (Riederer and Müller, 2006) prevents water losses (Riederer and Schreiber, 2001). It is a continuous structure $(0.1-10 \mu \mathrm{m}$ thick) formed by a combination of cutin, waxes and polysaccharides (Holloway, 1982; Jeffree, 1996). Due to its chemical properties, cuticle is permeable to lipophilic compounds (Schreiber, 2006) but represents a diffusion barrier to polar ones such as carbohydrates. Polar 
molecules can penetrate the leaf by transcuticular hydrophilic pores, the nature of which remains unclear (Schönherr, 2006; Schreiber, 2006), or through a stomatal pathway in which substances most likely move along the surfaces of the stomatal pores (Eichert and Goldbach, 2008) (Figure 1). The cuticular pathway has rather low size exclusion limits (around $2 \mathrm{~nm}$, compatible with diffusion of small carbohydrates such as sucrose) whereas the stomatal one enables entry of much greater molecules (over $43 \mathrm{~nm}$ in diameter) (Eichert et al., 2008). However, only a limited number of stomata seems to participate in this diffusion (less than $10 \%$ of all stomata in the case of Allium porrum L.; Eichert and Burkhardt, 2001). In the case of sucrose, penetration rate determined for an array of plant species was shown to range between $1 \%$ for astomatous cuticles and $4 \%$ for stomatous ones (Eichert and Goldbach, 2008). Therefore, in hypostomatal plant species, sucrose uptake across the abaxial surface was at least more than two times higher than that across the adaxial side. It is likely that penetration rate of OS, greater in size than sucrose, is even lower. These observations could account for variable and limited effectiveness of OS application as foliar sprays. For these reasons, it should be important to investigate formulation that can improve bioavailability of OS in leaf tissues (Liu et al., 2004; Fernández and Eichert, 2009).

\section{THE PHYLLOSPHERE IS PROBABLY NOT PASSIVE REGARDING OS APPLICATION}

Leaf surfaces of nearly all higher plants form the phyllosphere (Ruinen, 1961), habitats for epiphytic microorganisms including bacteria, yeasts and fungi (Vorholt, 2012). These leaf-associated microbes use resources such as carbohydrates, amino acids, and organic acids (Tukey, 1970; Derridj, 1996; Leveau and Lindow, 2001; Van Der Wal and Leveau, 2011) passively leaked by plants. Photoassimilates like sucrose, fructose, and glucose found in abundance $(0.2-2.0 \mu \mathrm{g}$ per leaf) on uninhabited bean leaf surfaces, were indeed readily consumed and converted into biomass by the inoculated bacterium Pseudomonas fluorescens (Mercier and Lindow, 2000). Bacterial and fungal colonization of the phyllosphere does not occur evenly across the leaf (Kinkel et al., 1995). Hence, bacteria are more likely to be found clustered in crevices between epidermal cells (anticlinal cell walls), near the base of trichomes, in the proximity of and in stomata, and along veins (Mansvelt and Hattingh, 1987; Davis and Brlansky, 1991). This location corresponds to putative cuticular diffusion sites of hydrophilic oligosaccharides. In this context, it is pertinent to wonder about the durability of oligosaccharides once sprayed onto the leaf surface. However, bacteria of the phyllosphere secrete biosurfactants (Cooper and Zajic, 1980; Neu, 1996; Rosenberg and Ron, 1999) that increase the wettability of leaf tissues (Bunster et al., 1989; Schreiber et al., 2005) or directly alter the leaf surface permeability (Schreiber et al., 2005), so one could expect that they contribute to enhanced diffusion of xenobiotics (such as OS) through the cuticle and along stomatal pores (Eichert and Goldbach, 2008).

In another way, it is well known that microbes, especially epiphytic fungi and bacteria surviving on crop plants produce and secrete a range of enzymes, especially glycoside hydrolases that degrade cell wall polysaccharides (Culleton et al., 2013). Among them are pectinases (most notably polygalacturonases), pectin and pectate lyases and pectin esterases directed against the homogalacturonan domain, as well as rhamnogalacturonases (Alghisi and Favaron, 1995; Chen et al., 1997; Abbott and Boraston, 2008). Other microorganisms could produce chitinases and also glucanases, alginate or ulvan lyases (Lahaye et al., 1997; Da Costa et al., 2001; Urquhart and Punja, 2002; Dahiya et al., 2006). By this way, one could hypothesize different possible scenarios for a sprayed OS: $i$ - it is not altered by the phyllosphere microflora, $i$ it is partly altered and hydrolyzed by the phyllosphere microflora, resulting in a lower active quantity bioavailable for defense induction and in the release of iii- small fragments having a higher elicitor activity or $i v$ - inactive small fragment or $v$ - small sugars acting as signaling molecules (especially in the case of $\beta$-glucan) (Figure 1). Phyllosphere microflora thus undoubtedly plays a role regarding oligosaccharidic bioavailability, although it remains difficult to describe it precisely.

\section{CONCLUSION}

It is now undeniable that carbohydrates play a role in plant immunity. However, their actual significance in plant-microbe interactions still remains partly unknown because of the high complexity of the mechanisms involved. As far as their use in crop protection is concerned, examples of successful applications demonstrate the potential of OS-based induced resistance as a strategy. However, OS treatments generally still suffer inconsistency. Many reasons can account for this situation among which a lack of suited formulation or degradation by epiphytic microorganisms can be hypothesized. Conversely to pesticides that act directly on pathogens, elicitor-induced resistance implies the elicitor perception by the plant and a subsequent plant response undoubtedly influenced by various factors. Progress in the identification of plant PRRs would guide the choice of the best OS candidates for crops and could be used as a criterion in plant breeding programs. PRR encoding genes could also have interest for transformation of plants lacking the corresponding PRR. The influence of various factors susceptible to modulate the plant response, such as the plant developmental stage, host and pathogen genotypes, abiotic stresses or nutrition factors, is still partially or unanswered and will require specific research. This should help OS to become part of disease control management, in combination with other strategies and reduce the use of pesticides.

\section{AUTHOR CONTRIBUTIONS}

All authors have substantially contributed to the conception and drafting of the manuscript: Adrien Gauthier (Section Induced Defenses and Resistance), Benoît Poinssot (Sections Perception and Structure/Activity Relationships of Carbohydrates), Christelle Guillier (Section The Phyllosphere is Probably Not Passive Regarding OS Application and References), Lucie Trdá (Section Perception), Franck Paris (Sections Main Classes of Carbohydrates Involved in Plant Immunity and The Cuticular Barrier), Marielle Adrian (Introduction, Section Sugars as Signaling Molecules and supervision of drafting), Maud Combier (Section Structure/Activity Relationships of Carbohydrates and design of the figure) Marie-Claire Héloir (Abstract, Sections Main Classes of Carbohydrates Involved in Plant 
Immunity, Perception and Structure/Activity Relationships of Carbohydrates), Sophie Trouvelot (Sections Main Classes of Carbohydrates Involved in Plant Immunity, Structure/Activity Relationships of Carbohydrates, The Cuticular Barrier, The Phyllosphere is Probably Not Passive Regarding OS Application and Table 1), Xavier Daire (Section A Still Limited Use and Conclusion). All authors revised the manuscript critically (under the overall supervision of Marie-Claire Héloir), approved the final version to be published and agree to be accountable for all aspects of the work.

\section{REFERENCES}

Abbott, D. W., and Boraston, A. B. (2008). Structural biology of pectin degradation by enterobacteriaceae. Microbiol. Mol. Biol. Rev. 72, 301-316. doi: 10.1128/MMBR.00038-07

Abreu, G. F., Talamini, V., and Stadnik, M. J. (2008). Bioprospecção de macroalgas marinhas e plantas aquáticas para o controle da antracnose do feijoeiro. Summa Phytopathol. 34, 78-82. doi: 10.1590/S0100-54052008000100017

Akimoto, C., Aoyagi, H., Dicosmo, F., and Tanaka, H. (2000). Synergistic effect of active oxygen species and alginate on chitinase production by wasabia japonica cells and its application. J Biosci. Bioeng. 89, 131-137. doi: 10.1016/S13891723(00)88726-5

Albersheim, P., Darvill, A. G., Mc Neil, M., Valent, B. S., Sharp, J. K., Nothnagel, E. A., et al. (1983). "Oligosaccharins: naturally occurring carbohydrates with biological regulatory functions," in Structure and Function of Plant Genomes, eds O. Ciferri and L. Dure (New York, NY: Plenum Press), 293-312. doi: 10.1007/978-1-4684-4538-1_30

Alghisi, P., and Favaron, F. (1995). Pectin-degrading enzymes and plant-parasite interactions. Eur. J. Plant Pathol. 101, 365-375. doi: 10.1007/bf01874850

Allègre, M., Héloir, M. C., Trouvelot, S., Daire, X., Pugin, A., Wendehenne, D., et al. (2009). Are grapevine stomata involved in the elicitor-induced protection against downy mildew? Mol. Plant Microbe Interact. 22, 977-986. doi: 10.1094/MPMI-22-8-0977

Amborabe, B. E., Bonmort, J., Fleurat-Lessard, P., and Roblin, G. (2008). Early events induced by chitosan on plant cells. J. Exp. Bot. 59, 2317-2324. doi: 10.1093/jxb/ern096

An, Q. D., Zhang, G. L., Wu, H. T., Zhang, Z. C., Zheng, G. S., Luan, L., et al. (2009). Alginate-deriving oligosaccharide production by alginase from newly isolated flavobacterium sp. Lxa and its potential application in protection against pathogens. J. Appl. Microbiol. 106, 161-170. doi: 10.1111/j.13652672.2008.03988.x

Araújo, L., and Stadnik, M. J. (2013). Cultivar-specific and ulvan-induced resistance of apple plants to Glomerella leaf spot are associated with enhanced activity of peroxidases. Acta Scient. Agronomy 35, 287-293. doi: 10.4025/actasciagron.v35i3.16174

Araujo, L., Stadnik, M. J., Borsato, L. C., and Valdebenito-Sanhueza, R. M. (2008). Potassium phosphite and ulvan in the control of "gala" leaf spot on apple. Trop. Plant Pathol. 33, 148-152. doi: 10.1590/s1982-56762008000200009

Ayers, A. R., Ebel, J., Valent, B., and Albersheim, P. (1976). Host-pathogen interactions.10. Fractionation and biological-activity of an isolated from mycelial walls of Phytophthora megasperma var sojae. Plant Physiol. 57, 760-765. doi: $10.1104 /$ pp.57.5.760

Aziz, A., Heyraud, A., and Lambert, B. (2004). Oligogalacturonide signal transduction, induction of defense-related responses and protection of grapevine against Botrytis cinerea. Planta 218, 767-774. doi: 10.1007/s00425-003-1153-x

Aziz, A., Poinssot, B., Daire, X., Adrian, M., Bézier, A., Lambert, B., et al. (2003). Laminarin elicits defense responses in grapevine and induces protection against Botrytis cinerea and Plasmopara viticola. Mol. Plant Microbe Interact. 16, 1118-1128. doi: 10.1094/MPMI.2003.16.12.1118

Barber, M. S., Bertram, R. E., and Ride, J. P. (1989). Chitin oligosaccharides elicit lignification in wounded wheat leaves. Physiol. Mol. Plant Pathol. 34, 3-12. doi: 10.1016/0885-5765(89)90012-X

Benhamou, N., Lafontaine, P. J., and Nicole, M. (1994). Seed treatment with chitosan induces systemic resistance to Fusarium crown and root rot in tomato plants. Phytopathology 84, 1432-1444. doi: 10.1094/Phyto-84-1432

Binet, M. N., Bourque, S., Lebrun-Garcia, A., Chiltz, A., and Pugin, A. (1998). Comparison of the effects of cryptogein and oligogalacturonides on tobacco cells and evidence of different forms of desensitization induced by these elicitors. Plant Sci. 137, 33-41. doi: 10.1016/S0168-9452(98)00132-0

Böhm, H., Albert, I., Fan, L., Reinhard, A., and Nürnberger, T. (2014). Immune receptor complexes at the plant cell surface. Curr. Opin. Plant Biol. 20C, 47-54. doi: 10.1016/j.pbi.2014.04.007

Boller, T., and Felix, G. (2009). A renaissance of elicitors: perception of microbe-associated molecular patterns and danger signals by pattern-recognition receptors. Annu. Rev. Plant Biol. 60, 379-406. doi: 10.1146/annurev.arplant.57.032905.105346

Bolouri-Moghaddam, M. R., and Van Den Ende, W. (2012). Sugars and plant innate immunity. J. Exp. Bot. 63, 3989-3998. doi: 10.1093/jxb/ers129

Bolouri-Moghaddam, M. R., and Van Den Ende, W. (2013). Sweet immunity in the plant circadian regulatory network. J. Exp. Bot. 64, 1439-1449. doi: $10.1093 / \mathrm{jxb} / \mathrm{ert} 046$

Bolouri-Moghaddam, M. R., Le Roy, K., Xiang, L., Rolland, F., and Van Den Ende, W. (2010). Sugar signalling and antioxidant network connections in plant cells. FEBS J. 277, 2022-2037. doi: 10.1111/j.1742-4658.2010.07633.x

Bolton, M. D. (2009). Primary metabolism and plant defense-fuel for the fire. Mol. Plant Microbe Interact. 22, 487-497. doi: 10.1094/MPMI-22-5-0487

Borsato, L. C., Di Piero, R. M., and Stadnik, M. J. (2010). Mechanisms of defense elicited by ulvan against uromyces appendiculatus in three bean cultivars. Trop. Plant Pathol. 35, 318-322. doi: 10.1590/S1982-56762010000500008

Bouarab, K., Potin, P., Correa, J., and Kloareg, B. (1999). Sulfated oligosaccharides mediate the interaction between a marine red alga and its green algal pathogenic endophyte. Plant Cell 11, 1635-1650. doi: 10.1105/tpc.11.9.1635

Boudart, G., Charpentier, M., Lafitte, C., Martinez, Y., Jauneau, A., Gaulin, E., et al. (2003). Elicitor activity of a fungal endopolygalacturonase in tobacco requires a functional catalytic site and cell wall localization. Plant Physiol. 131, 93-101. doi: 10.1104/pp.011585

Brutus, A., Sicilia, F., Macone, A., Cervone, F., and De Lorenzo, G. (2010). A domain SWAP approach reveals a role of the plant wall-associated kinase 1 (WAK1) as a receptor of oligogalacturonides. Proc. Natl. Acad. Sci. U.S.A. 107, 9452-9457. doi: $10.1073 /$ pnas. 1000675107

Bueter, C. L., Specht, C. A., and Levitz, S. M. (2013). Innate sensing of chitin and chitosan. PLoS Pathog. 9:e1003080. doi: 10.1371/journal.ppat.1003080

Bunster, L., Fokkema, N. J., and Schippers, B. (1989). Effect of surfaceactive Pseudomonas spp. on leaf wettability. Appl. Environ. Microbiol. 55, 1340-1345.

Cabrera, J. C., Boland, A., Cambier, P., Frettinger, P., and Van Cutsem, P. (2010). Chitosan oligosaccharides modulate the supramolecular conformation and the biological activity of oligogalacturonides in Arabidopsis. Glycobiology 20, 775-786. doi: 10.1093/glycob/cwq034

Cabrera, J. C., Boland, A., Messiaen, J., Cambier, P., and Van Cutsem, P. (2008). Egg box conformation of oligogalacturonides: the time-dependent stabiliza- tion of the elicitor-active conformation increases its biological activity. Glycobiology 18, 473-482. doi: 10.1093/glycob/cwn027

Cabrera, J. C., Messiaen, J., Cambier, P., and Van Cutsem, P. (2006). Size, acetylation and concentration of chitooligosaccharide elicitors determine the switch from de- fense involving PAL activation to cell death and water peroxide production in Arabidopsis cell suspensions. Physiol. Plant 127, 44-56. doi: 10.1111/j.13993054.2006.00677.x

Cardinale, F., Jonak, C., Ligterink, W., Niehaus, K., Boller, T., and Hirt, H. (2000). Differential activation of four specific MAPK pathways by distinct elicitors. J. Biol. Chem. 275, 36734-36740. doi: 10.1074/jbc.M007418200

Chandía, N. P., Matsuhiro, B., Mejías, E., and Moenne, A. (2004). Alginic acids in Lessonia vadosa: partial hydrolysis and elicitor properties of the polymannuronic acid fraction. J. Appl. Phycol. 16, 127-133. doi: 10.1023/B:JAPH.0000044778.44193.a8

Chen, H. J., Smith, D. L., Starrett, D. A., Zhou, D. B., Tucker, M. L., Solomos, T., et al. (1997). Cloning and characterization of a rhamnogalacturonan hydrolase gene from Botrytis cinerea. Biochem. Mol. Biol. Int. 43, 823-838.

Cheong, J. J., and Hahn, M. G. (1991). A specific, high-affinity binding site for the hepta-beta-glucoside elicitor exists in soybean membranes. Plant Cell 3, 137-147. doi: 10.1105/tpc.3.2.137

Chisholm, S. T., Coaker, G., Day, B., and Staskawicz, B. J. (2006). Host-microbe interactions: shaping the evolution of the plant immune response. Cell 124, 803-814. doi: 10.1016/j.cell.2006.02.008

Cluzet, S., Torregrosa, C., Jacquet, C., Lafitte, C., Fournier, J., Mercier, L., et al. (2004). Gene expression profiling and protection of Medicago truncatula against 
a fungal infection in response to an elicitor from green algae ulva spp. Plant Cell Environ. 27, 917-928. doi: 10.1111/j.1365-3040.2004.01197.x

Cooper, D. G., and Zajic, J. E. (1980). Surface-active compounds from microorganisms. Adv. Appl. Microbiol. 26, 229-253.

Côté, F., and Hahn, M. G. (1994). Oligosaccharins: structures and signal transduction. Plant Mol. Biol. 26, 1379-1411. doi: 10.1007/BF00016481

Côté, F., Ham, K., Hahn, M., and Bergmann, C. (1998). Oligosaccharide elicitors in host-pathogen interactions. Generation, perception, and signal transduction. Subcell. Biochem. 29, 385-432. doi: 10.1007/978-1-4899-1707-2_13

Culleton, H., McKie, V., and De Vries, R. P. (2013). Physiological and molecular aspects of degradation of plant polysaccharides by fungi: what have we learned from Aspergillus? Biotechnol. J. 8, 884-894. doi: 10.1002/biot.201200382

Da Costa, A., Michaud, P., Petit, E., Heyraud, A., Colin-Morel, P., Courtois, B., et al. (2001). Purification and properties of a glucuronan lyase from Sinorhizobium meliloti M5N1CS (NCIMB 40472). Appl. Environ. Microbiol. 67, 5197-5203. doi: 10.1128/aem.67.11.5197-5203.2001

Dahiya, N., Tewari, R., and Hoondal, G. S. (2006). Biotechnological aspects of chitinolytic enzymes: a review. Appl. Microbiol. Biotechnol. 71, 773-782. doi: 10.1007/s00253-005-0183-7

Davis, C. L., and Brlansky, R. H. (1991). Use of immunogold labelling with scanning electron microscopy to identify phytopathogenic bacteria on leaf surfaces. Appl. Environ. Microbiol. 57, 3052-3055.

Davis, K. R., Darvill, A. G., and Albersheim, P. (1986). Several biotic and abiotic elicitors act synergistically in the induction of phytoalexin accumulation in soybean. Plant Mol. Biol. 6, 23-32. doi: 10.1007/BF00021303

Davis, K. R., and Hahlbrock, K. (1987). Induction of defense responses in cultured parsley cells by plant cell wall fragments. Plant Physiol. 84, 1286-1290. doi: $10.1104 /$ pp.84.4.1286

Decreux, A., and Messiaen, J. (2005). Wall-associated kinase WAK1 interacts with cell wall pectins in a calcium-induced conformation. Plant Cell Physiol. 46, 268-278. doi: 10.1093/pcp/pci026

Delaunois, B., Farace, G., Jeandet, P., Clément, C., Baillieul, F., Dorey, S., et al. (2014). Elicitors as alternative strategy to pesticides in grapevine? Current knowledge on their mode of action from controlled conditions to vineyard. Environ. Sci. Pollut. Res. Int. 21, 4837-4846. doi: 10.1007/s11356-013-1841-4

Delgado, D. Z., de Freitas, M. B., and Stadnik, M. J. (2013). Effectiveness of saccharin and ulvan as resistance inducers against rust and angular leaf spot in bean plants (Phaseolus vulgaris). Crop Protect. 47, 67-73. doi: 10.1016/j.cropro.2013.01.003

Denoux, C., Galletti, R., Mammarella, N., Gopalan, S., Werck, D., De Lorenzo, G., et al. (2008). Activation of defense response pathways by OGS and Flg22 elicitors in Arabidopsis seedlings. Mol. Plant. 1, 423-445. doi: 10.1093/mp/ssn019

Derridj, S. (1996). "Nutrients on the leaf surface," in Aerial Plant Surface Microbiology, ed C. Nguyen-The (New York, NY: Plenum Press), 25-42. doi: 10.1007/978-0-585-34164-4_2

Dixon, R. A., Jennings, A. C., Davies, L. A., Gerrish, C., and Murphy, D. L. (1989). Elicitor-active components from French bean hypocotyls. Physiol. Mol. Plant Pathol. 34, 99-115. doi: 10.1016/0885-5765(89)90019-2

Doares, S. H., Syrovets, T., Weiler, E. W., and Ryan, C. A. (1995). Oligogalacturonides and chitosan activate plant defensive genes through the octadecanoid pathway. Proc. Natl. Acad. Sci. U.S.A. 92, 4095-4098. doi: 10.1073/pnas.92.10.4095

Ebel, J. (1998). Oligoglucoside elicitor-mediated activation of plant defense. Bioassays 20, 569-576.

Ebel, J., and Cosio, E. G. (1994). Elicitors of plant defense responses. Int. Rev. Cytol. 148, 1-36. doi: 10.1016/S0074-7696(08)62404-3

Eckardt, N. A. (2008). Chitin signaling in plants: insights into the perception of fungal pathogens and rhizobacterial symbionts. Plant Cell 20, 241-243. doi: 10.1105/tpc.108.058784

Ehness, R., Ecker, M., Godt, D. E., and Roitsch, T. (1997). Glucose and stress independently regulate source and sink metabolism and defense mechanisms via signal transduction pathways involving protein phosphorylation. Plant Cell 9, 1825-1841. doi: 10.1105/tpc.9.10.1825

Eichert, T., and Burkhardt, J. (2001). Quantification of stomatal uptake of ionic solutes using a new model system. J. Exp. Bot. 52, 771-781.

Eichert, T., and Goldbach, H. E. (2008). Equivalent pore radii of hydrophilic foliar uptake routes in stomatous and astomatous leaf surfaces - further evidence for a stomatal pathway. Physiol. Plant. 132, 491-502. doi: 10.1111/j.13993054.2007.01023
Eichert, T., Kurtz, A., Steiner, U., and Goldbach, H. E. (2008). Size exclusion limits and lateral heterogeneity of the stomatal foliar uptake pathway for aqueous solutes and water-suspended nanoparticles. Physiol. Plant. 134, 151-160. doi: 10.1111/j.1399-3054.2008.01135

El Ghaouth, A., Arul, J., Benhamou, N., Asselin, A., and Bélanger, R. R. (1994). Effect of chitosan on cucumber plants: suppression of Pythium aphanidermatum and induction of defence reactions. Phytopathology 84, 313-320. doi: 10.1094/Phyto-84-313

El Hadrami, A., Adam, L. R., El Hadrami, I., and Daayf, F. (2010). Chitosan in plant protection. Mar. Drugs 8, 968-987. doi: 10.3390/md8040968

Farmer, E., Moloshok, T., Saxton, M., and Ryan, C. (1991). Oligosaccharide signaling in plants. specificity of oligouronide-enhanced plasma membrane protein phosphorylation. J. Biol. Chem. 266, 3140-3145.

Felix, G., Regenass, M., and Boller, T. (1993). Specific perception of subnanomolar concentrations of chitin fragments by tomato cells: induction of extracellular alkalinization, changes in protein phosphorylation, and establishment of a refractory state. Plant J. 4, 307-316. doi: 10.1046/j.1365-313X.1993. 04020307.x

Fernández, V., and Eichert, T. (2009). Uptake of hydrophilic solutes through plant leaves: current state of knowledge and perspectives of foliar fertilization. Crit. Rev. Plant Sci. 28, 36-68. doi: 10.1080/07352680902743069

Fernandez, O., Bethencourt, L., Quero, A., Sangwan, R. S., and Clément, C. (2010). Trehalose and plant stress responses: friend or foe? Trends Plant Sci. 15, 409-417. doi: 10.1016/j.tplants.2010.04.004

Ferrari, S., Galletti, R., Denoux, C., De Lorenzo, G., Ausubel, F. M., and Dewdney, J. (2007). Resistance to Botrytis cinerea induced in Arabidopsis by elicitors is independent of salicylic acid, ethylene, or jasmonate signaling but requires PHYTOALEXIN DEFICIENT3. Plant Physiol. 144, 367-379. doi: 10.1104/pp.107.095596

Ferrari, S., Savatin, D. V., Sicilia, F., Gramegna, G., Cervone, F., and Lorenzo, G. D. (2013). Oligogalacturonides: plant damage-associated molecular patterns and regulators of growth and development. Front Plant Sci. 4:49. doi: 10.3389/fpls.2013.00049

Freitas, M. B., and Stadnik, M. J. (2012). Race-specific and ulvan-induced defense responses in bean (Phaseolus vulgaris) against Colletotrichum lindemuthianum. Physiol. Mol. Plant Pathol. 78, 8-13. doi: 10.1016/j.pmpp.2011.12.004

Fu, Y., Yin, H., Wanga, W., Wang, M., Zhang, H., Zhao, X., et al. (2011). $\beta$ 1,3-Glucan with different degree of polymerization induced different defense responses in tobacco. Carbohydr. Polym. 86, 774-782. doi: 10.1016/j.carbpol. 2011.05 .022

Galletti, R., Denoux, C., Gambetta, S., Dewdney, J., Ausubel, F. M., De Lorenzo, G., et al. (2008). The AtrbohD-mediated oxidative burst elicited by oligogalacturonides in Arabidopsis is dispensable for the activation of defense responses effective against Botrytis cinerea. Plant Physiol. 148, 1695-1706. doi: 10.1104/pp.108.127845

Gauthier, A., Trouvelot, S., Kelloniemi, J., Frettinger, P., Wendehenne, D., Daire, X., et al. (2014). The sulfated laminarin triggers a stress transcriptome before priming the SA- and ROS-dependent defenses during grapevine's induced resistance against Plasmopara viticola. PLoS ONE 9:e88145. doi: 10.1371/journal.pone.0088145

Ghannam, A., Jacques, A., De Ruffray, P., Baillieul, F., and Kauffmann, S. (2005) Identification of tobacco ESTs with a hypersensitive response (HR)-specific pattern of expression and likely involved in the induction of the HR and/or localized acquired resistance (LAR). Plant Physiol. Biochem. 43, 249-259. doi: 10.1016/j.plaphy.2005.02.001

Goddijn, O., and Smeekens, S. (1998). Sensing trehalose biosynthesis in plants. Plant J. 14, 143-146. doi: 10.1046/j.1365-313X.1998.00140.x

Godt, D. E., and Roitsch, T. (1997). Regulation and tissue-specific distribution of mRNAs for three extracellular invertase isoenzymes of tomato suggests an important function in establishing and maintaining sink metabolism. Plant Physiol. 115, 273-282. doi: 10.1104/pp.115.1.273

Gómez-Ariza, J., Campo, S., Rufat, M., Estopã, M., Messeguer, J., Segundo, B. S., et al. (2007). Sucrose-mediated priming of plant defense responses and broadspectrum disease resistance by overexpression of the maize pathogenesis-pelated PRms protein in Rice Plants. Mol. Plant Microbe Interact. 20, 832-842. doi: 10.1094/MPMI-20-7-0832

Gomez-Gomez, L., and Boller, T. (2000). Fls2: an LRR receptor-like kinase involved in the perception of the bacterial elicitor flagellin in Arabidopsis. Mol. Cell 5, 1003-1011. doi: 10.1016/S1097-2765(00)80265-8 
Granot, D., David-Schwartz, R., and Kelly, G. (2013). Hexose kinases and their role in sugar-sensing and plant development. Front. Plant Sci. 4:44. doi: 10.3389/fpls.2013.00044

Gust, A. A., Willmann, R., Desaki, Y., Grabherr, H. M., and Nurnberger, T. (2012). Plant LysM proteins: modules mediating symbiosis and immunity. Trends Plant Sci. 17, 495-502. doi: 10.1016/j.tplants.2012.04.003

Hadwiger, L. A. (2013). Multiple effects of chitosan on plant systems: solid science or hype. Plant Sci. 208, 42-49. doi: 10.1016/j.plantsci.2013.03.007

Hahn, M. G., Darvill, A. G., and Albersheim, P. (1981). Host-pathogen interactions: xix. The endogenous elicitor, a fragment of a plant cell wall polysaccharide that elicits phytoalexin accumulation in soybeans. Plant Physiol. 68, 1161-1169. doi: 10.1104/pp.68.5.1161

Hamel, L. P., and Beaudoin, N. (2010). Chitooligosaccharide sensing and downstream signaling: contrasted outcomes in pathogenic and beneficial plantmicrobe interactions. Planta 232, 787-806. doi: 10.1007/s00425-010-1215-9

Hayafune, M., Berisio, R., Marchetti, R., Silipo, A., Kayama, M., Desaki, Y., et al. (2014). Chitin-induced activation of immune signaling by the rice receptor CEBiP relies on a unique sandwich-type dimerization. Proc. Natl. Acad. Sci. U.S.A. 111, E404-E413. doi: 10.1073/pnas.1312099111

Herbers, K., Meuwly, P., Frommer, W. B., Metraux, J. P., and Sonnewald, U. (1996a). Systemic acquired resistance mediated by the ectopic expression of invertase: possible hexose sensing in the secretory pathway. Plant Cell 8, 793-803. doi: 10.1105/tpc.8.5.793

Herbers, K., Meuwly, P., Metraux, J. P., and Sonnewald, U. (1996b). Salicylic acid-independent induction of pathogenesis-related protein transcripts by sugars is dependent on leaf developmental stage. FEBS Lett. 397, 239-244. doi: 10.1016/S0014-5793(96)01183-0

Herbers, K., Takahata, Y., Melzer, M., Mock, H. P., Hajirezaei, M., and Sonnewald, U. (2000). Regulation of carbohydrate partitioning during the interaction of Potato virus Y with tobacco. Mol. Plant Pathol. 1, 51-59. doi: 10.1046/j.13643703.2000.00007.x

Holloway, P. J. (1982). “The chemical constitution of plant cutins," in The Plant Cuticle, eds D. F. Cutler, K. L. Alvin, and C. E. Pryce (London: Academic Press), 45-85.

Horsfall, J. G., and Dimond, A. E. (1957). Interactions of tissue sugar, growth substances, and disease susceptibility. Z. Pflanzenkr. Pflanzenschutz 64, 415-421.

Iizasa, E., Mitsutomi, M., and Nagano, Y. (2010). Direct binding of a plant LysM receptor-like kinase, LysM RLK1/CERK1, to chitin in vitro. J. Biol. Chem. 285, 2996-3004. doi: 10.1074/jbc.M109.027540

Inui, H., Yamaguchi, Y., and Hirano, S. (1997). Elicitor actions of $N$ acetylchitooligosaccharides and laminarioligosaccharides for chitinase and Lphenylalanine ammonia-lyase induction in rice suspension culture. Biosci. Biotechnol. Biochem. 61, 975-978. doi: 10.1271/bbb.61.975

Iriti, M., Vitalini, S., Di Tommaso, G., D’Amico, S., Borgo, M., and Faoro, F. (2011). New chitosan formulation prevents grapevine powdery mildew infection and improves polyphenol content and free radical scavenging activity of grape and wine. Aus. J. Grape Wine Res. 17, 263-269. doi: 10.1111/j.17550238.2011.00149.x

Iriti, M., and Faoro, F. (2009). Chitosan as a MAMP, searching for a PRR. Plant Signal. Behav. 4, 66-68. doi: 10.4161/psb.4.1.7408

Jang, J. C., Leon, P., Zhou, L., and Sheen, J. (1997). Hexokinase as a sugar sensor in higher plants. Plant Cell 9, 5-19. doi: 10.1105/tpc.9.1.5

Jaulneau, V., Lafitte, C., Corio-Costet, M. F., Stadnik, M., Salamagne, S., Briand, X., et al. (2011). An Ulva armoricana extract protects plants against three powdery mildew pathogens. Eur. J. Plant Pathol. 131, 393-401. doi: 10.1007/s10658-0119816-0

Jaulneau, V., Lafitte, C., Jacquet, C., Fournier, S., Salamagne, S., Briand, X., et al. (2010). Ulvan, a sulfated polysaccharide from green algae, activates plant immunity through the jasmonic acid signaling pathway. J. Biomed. Biotechnol. 2010:525291. doi: 10.1155/2010/525291

Jeffree, C. E. (1996). "Structure and ontogeny of plant cuticles," in Plant Cuticles: an Integrated Functional Approach, ed G. Kerstiens (Oxford: BIOS Scientific Publishers Ltd.), 33-82.

Jones, J. D., and Dangl, J. L. (2006). The plant immune system. Nature 444, 323-329. doi: 10.1038/nature05286

Kaku, H., Nishizawa, Y., Ishii-Minami, N., Akimoto-Tomiyama, C., Dohmae, N., Takio, K., et al. (2006). Plant cells recognize chitin fragments for defense signaling through a plasma membrane receptor. Proc. Natl. Acad. Sci. U.S.A. 103 11086-11091. doi: 10.1073/pnas.0508882103
Kaku, H., Shibuya, N., Xu, P., Aryan, A., and Fincher, G. (1997). Nacetylchitooligosaccharides elicit expression of a single (1,3)-beta-glucanase gene in suspension-cultured cells from barley (Hordeum vulgare). Physiol. Plant 100, 111-118. doi: 10.1111/j.1399-3054.1997.tb03460.x

Kawano, Y., and Shimamoto, K. (2013). Early signaling network in rice PRRmediated and R-mediated immunity. Curr. Opin. Plant. Biol. 16, 496-504. doi: 10.1016/j.pbi.2013.07.004

Keunen, E., Peshev, D., Vangronsveld, J., van den Ende, W., and Cuypers, A. (2013). Plant sugars are crucial players in the oxidative challenge during abiotic stress: extending the traditional concept. Plant Cell Env. 36, 1242, 1255. doi: $10.1111 /$ pce. 12061

Kim, M. S., Cho, S. M., Kang, E. Y., Im, Y. J., Hwangbo, H., Kim, Y. C., et al. (2008). Galactinol is a signaling component of the induced systemic resistance caused by Pseudomonas chlororaphis O6 root colonization. Mol. Plant Microbe Interact. 21, 1643-1653. doi: 10.1094/MPMI-21-12-1643

Kinkel, L. L., Wilson, M., and Lindow, S. E. (1995). Effect of sampling scale on the assessment of epiphytic bacterial populations. Microb. Ecol. 29, 283-297. doi: 10.1007/BF00164891

Kishimoto, K., Kouzai, Y., Kaku, H., Shibuya, N., Minami, E., and Nishizawa, Y. (2010). Perception of the chitin oligosaccharides contributes to disease resistance to blast fungus Magnaporthe oryzae in rice. Plant J. 64, 343-354. doi: 10.1111/j.1365-313X.2010.04328.x

Klarzynski, O., Descamps, V., Plesse, B., Yvin, J. C., Kloareg, B., and Fritig, B. (2003). Sulfated fucan oligosaccharides elicit defense responses in tobacco and local and systemic resistance against tobacco mosaic virus. Mol. Plant Microbe Interact. 16, 115-122. doi: 10.1094/MPMI.2003.16.2.115

Klarzynski, O., Plesse, B., Joubert, J. M., Yvin, J. C., Kopp, M., Kloareg, B., et al. (2000). Linear beta-1,3 glucans are elicitors of defense responses in tobacco. Plant Physiol. 124, 1027-1038. doi: 10.1104/pp.124.3.1027

Kobayashi, A., Tai, A., Kanzaki, H., and Kawazu, K. (1993). Elicitor-active oligosaccharides from algal laminaran stimulate the production of antifungal compounds in alfalfa. Z. Naturforsch 48C, 575-579.

Kocal, N., Sonnewald, U., and Sonnewald, S. (2008). Cell wall-bound invertase limits sucrose export and is involved in symptom development and inhibition of photosynthesis during compatible interaction between tomato and Xanthomonas campestris pv esicatoria. Plant Physiol. 148, 1523-1536. doi: 10.1104/pp.108.127977

Koch, K. (2004). Sucrose metabolism: regulatory mechanisms and pivotal roles in sugar sensing and plant development. Curr. Opin. Plant Biol. 7, 235-246. doi: 10.1016/j.pbi.2004.03.014

Koch, K. E. (1996). Carbohydrate-modulated gene expression in plants. Annu. Rev. Plant Physiol. Plant Mol. Biol. 47, 509-540. doi: 10.1146/annurev.arplant.47.1.509

Kohle, H., Jeblick, W., Poten, F., Blaschek, W., and Kauss, H. (1985). Chitosanelicited callose synthesis in soybean cells as a ca-dependent process. Plant Physiol. 77, 544-551. doi: 10.1104/pp.77.3.544

Kohorn, B. D., and Kohorn, S. L. (2012). The cell wall-associated kinases, WAKs, as pectin receptors. Front Plant Sci. 3:88. doi: 10.3389/fpls.2012. 00088

Kouzai, Y., Nakajima, K., Hayafune, M., Ozawa, K., Kaku, H., Shibuya, N., et al. (2014). CEBiP is the major chitin oligomer-binding protein in rice and plays a main role in the perception of chitin oligomers. Plant Mol. Biol. 84, 519-528. doi: 10.1007/s11103-013-0149-6

Kuchitsu, K., Kikuyama, M., and Shibuya, N. (1993). NAcetylchitooligosaccharides, biotic elicitor for phytoalexin production, induce transient membrane depolarization in suspension-cultured rice cells. Protoplasma 174, 79-81. doi: 10.1007/BF01404046

Lahaye, M., Brunel, M., and Bonnin, E. (1997). Fine chemical structure analysis of oligosaccharides produced by an ulvan-lyase degradation of the water-soluble cell-wall polysaccharides from Ulva sp, (Ulvales, Chlorophyta). Carbohydr. Res. 304, 325-333. doi: 10.1016/S0008-6215(97) 00270-X

Lahaye, M., and Robic, A. (2007). Structure and functional properties of ulvan, a polysaccharide from green seaweeds. Biomacromolecules 8, 1765-1774. doi: $10.1021 / \mathrm{bm} 061185 \mathrm{q}$

Lafontaine, P. J., and Benhamou, N. (1996). Chitosan treatment: an emerging strategy for enhancing resistance of greenhouse tomato plants to infection by Fusarium oxysporum f.sp. radicis-lycopersici. Biocontrol. Sci. Technol. 6, 111-124. doi: 10.1080/09583159650039575 
Lalonde, S., Boles, E., Hellmann, H., Barker, L., Patrick, J. W., Frommer, W. B., et al. (1999). The dual function of sugar carriers. Transport and sugar sensing. Plant Cell 11, 707-726. doi: 10.1105/tpc.11.4.707

Lee, S., Choi, H., Suh, S., Doo, I. S., Oh, K. Y., Choi, E. J., et al. (1999). Oligogalacturonic acid and chitosan reduce stomatal aperture by inducing the evolution of reactive oxygen species from guard cells of tomato and Commelina communis. Plant Physiol. 121, 147-152. doi: 10.1104/pp.121.1.147

Lee, W. S., Rudd, J. J., Hammond-Kosack, K. E., and Kanyuka, K. (2014). Mycosphaerella graminicola LysM effector-mediated stealth pathogenesis subverts recognition through both CERK1 and CEBiP homologues in wheat. Mol. Plant Microbe Interact. 27, 236-243. doi: 10.1094/MPMI-07-13-0201-R

Legendre, L., Rueter, S., Heinstein, P. F., and Low, P. S. (1993). Characterization of the oligogalacturonide-induced oxidative burst in cultured soybean (Glycine max) cells. Plant Physiol. 102, 233-240. doi: 10.1104/pp.102.1.233

Lepagnol-Descamps, V., Richard, C., Lahaye, M., Potin, P., Yvin, J. C., and Kloareg, B. (1998). Purification and determination of the action pattern of Haliotis tuberculata laminarinase. Carbohydr. Res. 310, 283-289. doi: 10.1016/S00086215(98)00181-5

Leveau, J. H., and Lindow, S. E. (2001). Appetite of an epiphyte: quantitative monitoring of bacterial sugar consumption in the phyllosphere. Proc. Natl. Acad. Sci. U.S.A. 98, 3446-3453. doi: 10.1073/pnas.061629598

Li, B., Liu, B., Shan, C., Ibrahim, M., Lou, Y., Wang, Y., et al. (2014). Antibacterial activity of two chitosan solutions and their effect on rice bacterial leaf blight and leaf streak. Pest. Manag. Sci. 69, 312-320. doi: 10.1002/ps.3399

Lionetti, V., Raiola, A., Camardella, L., Giovane, A., Obel, N., Pauly, M., et al. (2007). Overexpression of pectin methylesterase inhibitors in Arabidopsis restricts fungal infection by Botrytis cinerea. Plant Physiol. 143, 1871-1880. doi: 10.1104/pp.106.090803

Liu, Z. Q., Gaskin, R. E., and Zabkiwicz, J. A. (2004). Visualization of the effect of a surfactant on the uptake of xenobiotics into plant foliage by confocal laser scanning microscopy. Weed Res. 44, 237-243. doi: 10.1111/j.1365-3180.2004.00395.x

Lizzi, Y., Coulomb, C., Polian, C., Coulomb, P. J., and Coulomb, P. O. (1998). L'algue face au Mildiou quel avenir? Phytoma 508, 29-30.

Macho, A. P., and Zipfel, C. (2014). Plant PRRs and the activation of innate immune signaling. Mol. Cell. 54, 263-272. doi: 10.1016/j.molcel.2014.03.028

Mansvelt, E. L., and Hattingh, M. J. (1987). Scanning electron microscopy of pear blossom invasion by Pseudomonas syringae pv. Syringae. Can. J. Bot. 65, 2523-2529. doi: 10.1139/b87-342

Ménard, R., Alban, S., De Ruffray, P., Jamois, F., Franz, G., Fritig, B., et al. (2004). Beta-1,3 glucan sulfate, but not beta-1,3 glucan, induces the salicylic acid signaling pathway in Tobacco and Arabidopsis. Plant Cell 16, 3020-3032. doi: 10.1105/tpc. 104.024968

Ménard, R., De Ruffray, P., Fritig, B., Yvin, J. C., and Kauffmann, S. (2005). Defense and resistance-inducing activities in tobacco of the sulfated beta-1,3 glucan PS3 and its synergistic activities with the unsulfated molecule. Plant Cell Physiol. 46, 1964-1972. doi: 10.1093/pcp/pci212

Mercier, J., and Lindow, S. E. (2000). Role of leaf surface sugars in colonization of plants by bacterial epiphytes. Appl. Environ. Microbiol. 66, 369-374. doi: 10.1128/AEM.66.1.369-374.2000

Mercier, L., Lafitte, C., Borderies, G., Briand, X., Esquerré-Tugayé, M. T., and Fournier, J. (2001). The algal polysaccharide carrageenans can act as an elicitor of plant defence. New Phytol. 149, 43-51. doi: 10.1046/j.1469-8137.2001. 00011.x

Merzendorfer, H. (2011). The cellular basis of chitin synthesis in fungi and insects: common principles and differences. Eur. J. Cell Biol. 90, 759-769. doi: 10.1016/j.ejcb.2011.04.014

Miya, A., Albert, P., Shinya, T., Desaki, Y., Ichimura, K., Shirasu, K., et al. (2007). CERK1, a LysM receptor kinase, is essential for chitin elicitor signaling in Arabidopsis. Proc. Natl. Acad. Sci. U.S.A. 104, 19613-19618. doi: 10.1073/pnas.0705147104

Moerschbacher, B. M., Noll, U., Gorrichon, L., and Reisener, H. J. (1990). Specific inhibition of lignification breaks hypersensitive resistance of wheat to stem rust. Plant Physiol. 93, 465-470. doi: 10.1104/pp.93.2.465

Mohammadi, M., Zamani, A., and Karimi, K. (2012). Determination of gluosamine in fungal cell walls by high-performance liquid chromatography (HPLC). J. Agric. Food Chem. 60, 10511-10515. doi: 10.1021/jf303488w

Monaghan, J., and Zipfel, C. (2012). Plant pattern recognition receptor complexes at the plasma membrane. Curr. Opin. Plant. Biol. 15, 349-357. doi: 10.1016/j.pbi.2012.05.006
Morkunas, I., Marczak, L., Stachowiak, J., and Stobiecki, M. (2005). Sucroseinduced lupine defense against Fusarium oxysporum. Sucrose-stimulated accumulation of isoflavonoids as a defense response of lupine to Fusarium oxysporum. Plant Physiol. Biochem. 43, 363-373. doi: 10.1016/j.plaphy.2005.02.011

Muchembled, J., Sahraoui, A. L., Grandmougin-Ferjani, A., and Sancholle, M. (2006). Changes in lipid composition of Blumeria graminis f. sp. Tritici conidia produced on wheat leaves treated with heptanoyl salicylic acid. Phytochemistry 67, 1104-1109. doi: 10.1016/j.phytochem.2006.02.025

Navazio, L., Moscatiello, R., Bellincampi, D., Baldan, B., Meggio, F., Brini, M., et al. (2002). The role of calcium in oligogalacturonide-activated signalling in soybean cells. Planta 215, 596-605. doi: 10.1007/s00425-002-0776-7

Neu, T. R. (1996). Significance of bacterial surface-active compounds in interaction of bacteria with interfaces. Microbiol. Rev. 60, 151-166.

Nothnagel, E. A., McNeil, M., Albersheim, P., and Dell, A. (1983). Host-pathogen interactions: XXII. A galacturonic acid oligosaccharide from plant cell walls elicits phytoalexins. Plant Physiol. 71, 916-926. doi: 10.1104/pp.71.4.916

Nürnberger, T., Brunner, F., Kemmerling, B., and Piater, L. (2004). Innate immunity in plants and animals: striking similarities and obvious differences. Immunol. Rev. 198, 249-266. doi: 10.1111/j.0105-2896.2004.0119.x

Osorio, S., Castillejo, C., Quesada, M. A., Medina-Escobar, N., Brownsey, G. J., Suau, R., et al. (2008). Partial demethylation of oligogalacturonides by pectin methyl esterase 1 is required for eliciting defence responses in wild Strawberry (Fragaria vesca). Plant J. 54, 43-55. doi: 10.1111/j.1365-313X.2007.03398.x

Patier, P., Potin, P., Rochas, C., Kloareg, B., Yvin, J. C., and Liénart, Y. (1995). Free and silica-bound oligokappa-carrageenans elicit laminarase activity in Rubus cells and protoplasts. Plant Sci. 110, 27-35. doi: 10.1016/0168-9452(95)04182-T

Pearce, R. B., and Ride, J. P. (1982). Chitin and related compounds as elicitors of the lignification response in wounded wheat leaves. Physiol. Plant Pathol. 20, 119-123. doi: 10.1016/0048-4059(82)90030-3

Pelloux, J., Rusterucci, C., and Mellerowicz, E. J. (2007). New insights into pectin methylesterase structure and function. Trends Plant Sci. 12, 267-277. doi: 10.1016/j.tplants.2007.04.001

Petutschnig, E. K., Jones, A. M., Serazetdinova, L., Lipka, U., and Lipka, V. (2010). The lysin motif receptor-like kinase (LysM-RLK) CERK1 is a major chitinbinding protein in Arabidopsis thaliana and subject to chitin-induced phosphorylation. J. Biol. Chem. 285, 28902-28911. doi: 10.1074/jbc.M110.116657

Potin, P., Bouarab, K., Kupper, F., and Kloareg, B. (1999). Oligosaccharide recognition signals and defence reactions in marine plant-microbe interactions. Curr. Opin. Microbiol. 2, 276-283. doi: 10.1016/S1369-5274(99)80048-4

Randoux, B., Renard-Merlier, D., Mulard, G., Rossard, S., Duyme, F., Sanssene, J., et al. (2010). Distinct defenses induced in wheat against powdery mildew by acetylated and nonacetylated oligogalacturonides. Phytopathology 100, 1352-1363. doi: 10.1094/PHYTO-03-10-0086

Rasul, S., Dubreuil-Maurizi, C., Lamotte, O., Koen, E., Poinssot, B., Alcaraz, G., et al. (2012). Nitric oxide production mediates oligogalacturonide-triggered immunity and resistance to Botrytis cinerea in Arabidopsis thaliana. Plant Cell Environ. 35, 1483-1499. doi: 10.1111/j.1365-3040.2012.02505.x

Read, S. M., Currie, G., and Bacic, A. (1996). Analysis of the structural heterogeneity of laminarin by electrospray-ionisation-mass spectrometry. Carbohydrate Res. 281, 187-201. doi: 10.1016/0008-6215(95)00350-9

Reignault, P. H., Cogan, A., Muchembled, J., Lounes-Hadj Sahraoui, A., Durand, R., and Sancholle, M. (2001). Trehalose induces resistance to powdery mildew in wheat. New Phytol. 149, 519-529. doi: 10.1046/j.1469-8137.2001. 00035.x

Renard-Merlier, D., Randoux, B., Nowak, E., Farcy, F., Durand, R., and Reignault, P. (2007). Iodus 40, salicylic acid, heptanoyl salicylic acid and trehalose exhibit different efficacies and defence targets during a wheat/powdery mildew interaction. Phytochemistry 68, 1156-1164. doi: 10.1016/j.phytochem.2007. 02.011

Reymond, P., Grunberger, S., Paul, K., Muller, M., and Farmer, E. E. (1995). Oligogalacturonide defense signals in plants: large fragments interact with the plasma membrane in vitro. Proc. Natl. Acad. Sci. U.S.A. 92, 4145-4149. doi: 10.1073/pnas.92.10.4145

Riederer, M., and Müller, C. (eds.). (2006). Biology of the Plant Cuticle. Annual Plant Reviews. Vol. 23. Oxford, UK: Blackwell publishing. doi: 10.1002/9780470988718

Riederer, M., and Schreiber, L. (2001). Protecting against water loss: analysis of the barrier properties of plant cuticles. J. Exp. Bot. 52, 2023-2032. doi: $10.1093 /$ jexbot/52.363.2023 
Robertsen, B. (1986). Elicitors of the production of lignin- like compounds in cucumber hypocotyls. Physiol. Mol. Plant Pathol. 28, 137-148. doi: 10.1016/S0048-4059(86)80015-7

Roby, D., Gadelle, A., and Toppan, A. (1987). Chitin oligosaccharides as elicitors of chitinase activity in melon plants. Biochem. Biophys. Res. Commun. 143, 885-892. doi: 10.1016/0006-291X(87)90332-9

Roitsch, T., Balibrea, M. E., Hofmann, M., Proels, R., and Sinha, A. K. (2003). Extracellular invertase: key metabolic enzyme and PR protein. J. Exp. Bot. 54, 513-524. doi: 10.1093/jxb/erg050

Roitsch, T., and Gonzalez, M. C. (2004). Function and regulation of plant invertases: sweet sensations. Trends Plant Sci. 9, 606-613. doi: 10.1016/j.tplants.2004.10.009

Rolland, F., Baena-Gonzalez, E., and Sheen, J. (2006). Sugar sensing and signaling in plants: conserved and novel mechanisms. Annu. Rev. Plant Biol. 57, 675-709. doi: 10.1146/annurev.arplant.57.032905.105441

Rolland, F., Moore, B., and Sheen, J. (2002). Sugar sensing and signaling in plants. Plant Cell 14(Suppl.), S185-S205. doi: 10.1105/tpc.010455

Rosenberg, E., and Ron, E. Z. (1999). High- and Low-molecular-mass microbial surfactants. Appl. Microbiol. Biotechnol. 52, 154-162. doi: $10.1007 / \mathrm{s} 002530051502$

Rouet-Mayer, M., Mathieu, Y., Cazale, A., Guern, J., and Lauriere, C. (1997). Extracellular alkalinization and oxidative burst induced by fungal pectin lyase in tobacco cells are not due to the perception of oligogalacturonide fragments. Plant Physiol. Biochem. 35, 321-330.

Ruinen, J. (1961). The phyllosphere. Plant Soil 15, 81-109. doi: 10.1007/bf01347221

Sangha, J. S., Ravichandran, S., Prithiviraj, K., Critchley, A. T., and Prithiviraj, B. (2010). Sulfated macroalgal polysaccharides $\lambda$-carrageenan and $\iota$-carrageenan differentially alter Arabidopsis thaliana resistance to Sclerotinia sclerotiorum. Physiol. Mol. Plant Pathol. 75, 38-45. doi: 10.1016/j.pmpp.2010.08.003

Schaarschmidt, S., Kopka, J., Ludwig-Müller, J., and Hause, B. (2007). Regulation of arbuscular mycorrhization by apoplastic invertases: enhanced invertase activity in the leaf apoplast affects the symbiotic interaction. Plant J. 51, 390-405. doi: 10.1111/j.1365-313X.2007.03150.x

Schluepmann, H., Pellny, T., Van Dijken, A., Smeekens, S., and Paul, M. (2003). Trehalose 6-phosphate is indispensable for carbohydrate utilization and growth in Arabidopsis thaliana. Proc. Natl. Acad. Sci. U.S.A. 100, 6849-6854. doi: $10.1073 /$ pnas.1132018100

Schonherr, J. (2006). Characterization of aqueous pores in plant cuticles and permeation of ionic solutes. J. Exp. Bot. 57, 2471-2491. doi: 10.1093/jxb/ erj217

Schreiber, L. (2006). Review of sorption and diffusion of lipophilic molecules in cuticular waxes and the effects of accelerators on solute mobilities. J. Exp. Bot. 57, 2515-2523. doi: 10.1093/jxb/erj173

Schreiber, L., Krimm, U., Knoll, D., Sayed, M., Auling, G., and Kroppenstedt, R. M. (2005). Plant-microbe interactions: identification of epiphytic bacteria and their ability to alter leaf surface permeability. New Phytol. 166, 589-594. doi: 10.1111/j.1469-8137.2005.01343.x

Sharathchandra, R. G., Raj, S. N., Shetty, N. P., Amruthesh, K. N., and Shetty, H. S. (2004). A chitosan formulation ElexaTM induces downy mildew disease resistance and growth promotion in pearl millet. Crop Prot. 23, 881-888. doi: 10.1016/j.cropro.2003.12.008

Sharp, R. G. (2013). A review of the applications of chitin and its derivatives in agriculture to modify plant-microbial interactions and improve crop yields. Agronomy 3, 757-793. doi: 10.3390/agronomy3040757

Sharp, J. K., Valent, B., and Albersheim, P. (1984). Purification and partial characterization of a beta-glucan fragment that elicits phytoalexin accumulation in soybean. J. Biol. Chem. 259, 11312-11320.

Sheen, J., Zhou, L., and Jang, J. C. (1999). Sugars as signaling molecules. Curr. Opin. Plant Biol. 2, 410-418. doi: 10.1016/S1369-5266(99)00014-X

Shibuya, N., and Minami, E. (2001). Oligosaccharide signalling for defence responses in plant. Physiol. Mol. Plant Pathol. 59, 223-233. doi: 10.1006/pmpp.2001.0364

Shimizu, T., Nakano, T., Takamizawa, D., Desaki, Y., Ishii-Minami, N., Nishizawa, Y., et al. (2010). Two LysM receptor molecules, CEBiP and OsCERK1, cooperatively regulate chitin elicitor signaling in rice. Plant J. 64, 204-214. doi: 10.1111/j.1365-313X.2010.04324.x

Shiu, S. H., and Bleecker, A. B. (2003). Expansion of the receptor-like kinase/PELLE gene family and receptor-like proteins in Arabidopsis. Plant Physiol. 132, 530-543. doi: 10.1104/pp.103.021964
Simpson, S. D., Ashford, D. A., Harvey, D. J., and Bowles, D. J. (1998). Short chain oligogalacturonides induce ethylene production and expression of the gene encoding aminocyclopropane 1-carboxylic acid oxidase in tomato plants. Glycobiology 8, 579-583. doi: 10.1093/glycob/8.6.579

Singh, V., Louis, J., Ayre, B. G., Reese, J. C., Pegadaraju, V., and Shah, J. (2011) Trehalose phosphate synthase11-dependent trehalose metabolism promotes arabidopsis thaliana defense against the phloem-feeding insect myzus persicae. Plant J. 67, 94-104. doi: 10.1111/j.1365-313X.2011.04583.x

Smeekens, S. (2000). Sugar-induced signal transduction in plants. Annu. Rev. Plant Physiol. Plant Mol. Biol. 51, 49-81. doi: 10.1146/annurev.arplant.51.1.49

Smeekens, S., Ma, J., Hanson, J., and Rolland, F. (2010). Sugar signals and molecular networks controlling plant growth. Curr. Opin. Plant Biol. 13, 274-279. doi: 10.1016/j.pbi.2009.12.002

Stadnik, M. J., and De Freitas, M. B. (2014). Algal polysaccharides as source of plant resistance inducers. Trop. Plant Pathol. 39, 111-118. doi: 10.1590/S1982-567620 14000200001

Steimetz, E., Trouvelot, S., Gindro, K., Bordier, A., Poinssot, B. T., Adrian, M., et al. (2012). Influence of leaf age on induced resistance in grapevine against Plasmopara viticola. Physiol. Mol. Plant Pathol. 79, 89-96. doi: 10.1016/j.pmpp.2012.05.004

Stennis, M., Chandra, S., Ryan, C., and Low, P. (1998). Systemin potentiates the oxidative burst in cultured tomato cells. Plant Physiol. 117, 1031-1036. doi: 10.1104/pp.117.3.1031

Tanabe, S., Okada, M., Jikumaru, Y., Yamane, H., Kaku, H., Shibuya, N., et al. (2006). Induction of resistance against rice blast fungus in rice plants treated with a potent elicitor, $N$-acetylchitooligosaccharide. Biosci. Biotechnol. Biochem. 70, 1599-1605. doi: 10.1271/bbb.50677

Tang, X., Ruffner, H. P., Scholes, J. D., and Rolfe, S. A. (1996). Purification and characterisation of soluble invertases from leaves of Arabidopsis thaliana. Planta 198, 17-23. doi: 10.1007/BF00197581

Thibaud, M. C., Gineste, S., Nussaume, L., and Robaglia, C. (2004). Sucrose increases pathogenesis-related PR-2 gene expression in Arabidopsis thaliana through an SA-dependent but NPR1-independent signaling pathway. Plant Physiol. Biochem. 42, 81-88. doi: 10.1016/j.plaphy.2003.10.012

Tiessen, A., and Padilla-Chacon, D. (2013). Subcellular compartmentation of sugar signaling: links among carbon cellular status, route of sucrolysis, sinksource allocation, and metabolic partitioning. Front. Plant Sci. 3:306. doi: 10.3389/fpls.2012.00306

Trotel-Aziz, P., Couderchet, M., Vernet, G., and Aziz, A. (2006). Chitosan stimulates defense reactions in grapevine leaves and inhibits development of Botrytis cinerea. Eur. J. Plant Pathol. 114, 405-413. doi: 10.1007/s10658-006-0005-5

Trouvelot, S., Varnier, A. L., Allègre, M., Mercier, L., Baillieul, F., Arnould, C., et al. (2008). A beta-1,3 glucan sulfate induces resistance in grapevine against Plasmopara viticola through priming of defense responses, including HR-like cell death. Mol. Plant Microbe Interact. 21, 232-243. doi: 10.1094/MPMI-212-0232

Tukey, H. B. (1970). Leaching of substances from plants. Ann. Rev. Plant Physiol. 21, 305. doi: 10.1146/annurev.pp.21.060170.001513

Urquhart, E. J., and Punja, Z. K. (2002). Hydrolytic enzymes and antifungal compounds produced by Tilletiopsis species, phyllosphere yeasts that are antagonists of powdery mildew fungi. Can. J. Microbiol. 48, 219-229. doi: 10.1139/w02-008

Van Aubel, G. (2013). "Working Group: Induced resistance in plants against insects and diseases," in Proceedings of the Meeting - Leaping from Success in the Lab to Success in the Field, Vol. 89, eds M. Bardin, B. Mauch-Mani, S. Mazzotta, P. Nicot, C. Pieterse, J. L. Poessel, et al. (Avignon), 403-407.

Van Der Wal, A., and Leveau, J. H. (2011). Modelling sugar diffusion across plant leaf cuticles: the effect of free water on substrate availability to phyllosphere bacteria. Environ. Microbiol. 13, 792-797. doi: 10.1111/j.1462-2920.2010.02382.x

Vander, P., Vrum, K. M., Domard, A., Eddine El Gueddari, N., and Moerschbacher, B. M. (1998). Comparison of the ability of partially $N$-acetylated chitosans and chitooligosaccharides to elicit resistance reactions in wheat leaves. Plant Physiol. 118, 1353-1359. doi: 10.1104/pp.118.4.1353

Vasil'ev, L. A., Dzyubinskaya, E. V., Zinovkin, R. A., Kiselevsky, D. B., Lobysheva, N. V., and Samuilov, V. D. (2009). Chitosan-induced programmed cell death in plants. Biochemistry (Moscow) 74, 1035-1043. doi: 10.1134/S0006297909090120

Vasyukova, N. I., Zinov'eva, S. V., Il'inskaya, L. I., Perekhod, E. A., Chalenko, G. I., Gerasimova, N. G., et al. (2001). Modulation of plant resistance to diseases by water-soluble chitosan. App. Biochem. Microbiol. 37, 103-109. doi: 10.1023/A:1002865029994 
Vera, J., Castro, J., Contreras, R. A., GonzÃlez, A., and Moenne, A. (2012). Oligocarrageenans induce a long-term and broad-range protection against pathogens in tobacco plants (var. Xanthi). Physiol. Mol. Plant Pathol. 79, 31-39. doi: 10.1016/j.pmpp.2012.03.005

Vidal, S., Eriksson, A. R. B., Montesano, M., Denecke, J., and Palva, E. T. (1998). Cell wall-degrading enzymes from Erwinia carotovora cooperate in the salicylic acidindependent induction of a plant defense response. Mol. Plant Microbe Interact. 11, 23-32. doi: 10.1094/MPMI.1998.11.1.23

Vorholt, J. A. (2012). Microbial life in the phyllosphere. Nat. Rev. Microbiol. 10, 828-840. doi: 10.1038/nrmicro2910

Vorholter, F. J., Wiggerich, H. G., Scheidle, H., Sidhu, V. K., Mrozek, K., Kuster, H., et al. (2012). Involvement of bacterial TonB-dependent signaling in the generation of an oligogalacturonide damage-associated molecular pattern from plant cell walls exposed to Xanthomonas campestris pv. Campestris pectate lyases. BMC Microbiol. 12:239. doi: 10.1186/1471-2180-12-239

Wahl, R., Wippel, K., Goos, S., Kamper, J., and Sauer, N. (2010). A novel highaffinity sucrose transporter is required for virulence of the plant pathogen Ustilago maydis. PLoS Biol. 8:e1000303. doi: 10.1371/journal.pbio.1000303

Walters, D. R., Ratsep, J., and Havis, N. D. (2013). Controlling crop diseases using induced resistance: challenges for the future. J. Exp. Bot. 64, 1263-1280. doi: 10.1093/jxb/ert026

Wan, J., Zhang, X. C., and Stacey, G. (2008). Chitin signaling and plant disease resistance. Plant Signal. Behav. 3, 831-833. doi: 10.4161/psb.3.10.5916

Weber, J., Olsen, O., Wegener, C., and Von Wettstein, D. (1996). Digalacturonates from pectin degradation induce tissue responses against potato soft rot. Physiol. Mol. Plant Pathol. 48, 389-401. doi: 10.1006/pmpp.1996.0031

Wind, J., Smeekens, S., and Hanson, J. (2010). Sucrose: metabolite and signaling molecule. Phytochemistry 71, 1610-1614. doi: 10.1016/j.phytochem.2010. 07.007

Xiang, L., Li, Y., Rolland, F., and Van Den Ende, W. (2011). Neutral invertase, hexokinase and mitochondrial ROS homeostasis: emerging links between sugar metabolism, sugar signaling and ascorbate synthesis. Plant Signal. Behav. 6, 1567-1573. doi: 10.4161/psb.6.10.17036
Yamaguchi, K., Yamada, K., Ishikawa, K., Yoshimura, S., Hayashi, N., Uchihashi, K., et al. (2013). A receptor-like cytoplasmic kinase targeted by a plant pathogen effector is directly phosphorylated by the chitin receptor and mediates rice immunity. Cell Host Microbe 13, 347-357. doi: 10.1016/j.chom.2013.02.007

Yamaguchi, T., Yamada, A., Hong, N., Ogawa, T., Ishii, T., and Shibuya, N. (2000). Differences in the recognition of glucan elicitor signals between rice and soybean: beta-glucan fragments from the rice blast disease fungus Pyricularia oryzae that elicit phytoalexin biosynthesis in suspension-cultured rice cells. Plant Cell 12, 817-826. doi: 10.1105/tpc.12.5.817

Zipfel, C. (2008). Pattern-recognition receptors in plant innate immunity. Curr. Opin. Immunol. 20, 10-16. doi: 10.1016/j.coi.2007.11.003

Zipfel, C., and Felix, G. (2005). Plants and animals: a different taste for microbes? Curr. Opin. Plant Biol. 8, 353-360. doi: 10.1016/j.pbi.2005.05.004

Conflict of Interest Statement: The authors declare that the research was conducted in the absence of any commercial or financial relationships that could be construed as a potential conflict of interest.

Received: 25 July 2014; accepted: 11 October 2014; published online: 04 November 2014.

Citation: Trouvelot S, Héloir M-C, Poinssot B, Gauthier A, Paris F, Guillier C, Combier $M$, Trdá L, Daire X and Adrian M (2014) Carbohydrates in plant immunity and plant protection: roles and potential application as foliar sprays. Front. Plant Sci. 5:592. doi: $10.3389 / \mathrm{fpls} .2014 .00592$

This article was submitted to Crop Science and Horticulture, a section of the journal Frontiers in Plant Science.

Copyright (C) 2014 Trouvelot, Héloir, Poinssot, Gauthier, Paris, Guillier, Combier, Trdá, Daire and Adrian. This is an open-access article distributed under the terms of the Creative Commons Attribution License (CC BY). The use, distribution or reproduction in other forums is permitted, provided the original author(s) or licensor are credited and that the original publication in this journal is cited, in accordance with accepted academic practice. No use, distribution or reproduction is permitted which does not comply with these terms. 